\title{
Modeling the Rise of the City: Early Urban Networks in Southern Italy
}

\author{
Lieve Donnellan* \\ School of Culture and Society, Aarhus University, Aarhus, Denmark
}

The rise of the state in Ancient Italy went hand in hand with an increase in infrastructural power, i.e., settlement centralization and urbanization. The paper discusses theoretical challenges and introduces a modeling approach to a case study, one of the earliest cities in Southern Italy, Pontecagnano, with the aim of understanding the community dynamics at the time of the earliest urbanization (ca. 900-600 BC). The model is a two-mode model that derives from social network analysis, an approach that has been fruitfully adapted to archaeological research. The model is applied to detect trends in burial contexts from the community involved. Burial was, at that time, in the region, a key instrument in the creation of memory and display of status and thus for building and consolidating state power. The analytical network model is able to detect the dynamics in the community over time very well: network Cohesion is expanding and contracting, and points to the

OPEN ACCESS

Edited by:

Francesca Fulminante, University of Bristol, United Kingdom

Reviewed by:

César Parcero-Oubiña, Spanish National Research Council (CSIC), Spain Philip Verhagen, Vrije Universiteit University Amsterdam, Netherlands

*Correspondence: Lieve Donnellan I.donnellan@cas.au.dk

Specialty section: This article was submitted to

Digital Archaeology,

a section of the journal

Frontiers in Digital Humanities

Received: 15 January 2019

Accepted: 22 August 2019

Published: 10 September 2019

Citation:

Donnellan L (2019) Modeling the Rise of the City: Early Urban Networks in

Southern Italy.

Front. Digit. Humanit. 6:15. doi: 10.3389/fdigh.2019.00015 existence of tension and a tight control of funerary behavior. The study of Centrality of selected nodes provides a good understanding of the strategies in terms of the circulation of key resources. The latter is particularly significant for studying urbanization because the appropriation of resources was not possible without centralization and the development of infrastructure, as well as an ideology. Based on the study of selected resources, it is suggested that an increase in crop storage has played a particular role in the development of state power and the urbanization process at Pontecagnano. In due course, the paper also addresses methodological challenges of working with fragmented datasets when applying models to study the past.

Keywords: modeling, ancient cities, urbanization, archaeology, Southern Italy, network theory

\section{INTRODUCTION}

The appearance of cities sparked a process of deep transformation in the Ancient World. The Ancient Cities of the first millennium BC testify to a dramatic change in economic integration, social interaction and political complexity-a leap forward on a global scale which was never fully undone. The philosopher Karl Jaspers coined the term "Axial Age" to indicate this evolution which appeared more or less simultaneously in China, India, Persia, and Europe (Jaspers, 1949).

The first scholar to write extensively about the Ancient City, Fustel de Coulange (1980), is indicative for the general approach to urbanization as a historical process: “... just as several phratries were united in a tribe, several tribes might associate together, on the condition that the religion of each should be respected. The day on which this alliance took place the city existed. It is of little account to seek the cause which determined several neighboring tribes to unite" (Fustel de Coulange, 1980, p. 119). Fustel de Coulange considered religion to be the binding force of the Ancient City, independent of whether the tribes united voluntarily or were 
coerced by an external force. Cities underwent a series of transformations, in his view, as the result of lower social classes (the plebeians) demanding the right of involvement in political government. The "revolutions" he identified as the motor behind social change, did occur in all ancient cities, but not at the same time.

Archaeologists and historians did not really pick up on the theoretical challenges of defining the Ancient City, but Fustel de Coulange was very influential for later conceptualizations of cities and society among sociologists, through his most famous student Emile Durkheim. Other social thinkers, especially those interested in the city and urban phenomena, such as Weber (1921) in his posthumously published work discussed extensively the conditions of Ancient Cities such as Rome or Athens (among others). Likewise, the Ancient City occupies a central place among prominent early scholars of Urban Studies such as Simmel (1903) and Spengler (1922). Their studies, however, were based on the consensus of the day and did not contribute to a critical re-evaluation of Ancient Cities or urbanization processes among historians and archaeologists. Even today, despite the long history of interdisciplinary interaction and the comparative value that Ancient Cities bring to Modern Cities and vice versa, little is done to bridge the gap between sociology and the historical sciences.

Only in 1950 did an extensive comparative study by Childe result in a critical evaluation of archaeological and historical aspects of the urban character of settlements (Childe, 1950). Childe advocated the use of a checklist approach to distinguish cities from other settlements and he heavily favored monuments, law, writing, the market for exchange, and high culture as identifying elements. This checklist approach remained in favor for many decades among archaeologists and only more recently have more subtle ways of tackling the question of the nature and coming into being of Ancient Cities been proposed for the Mediterranean (Damgaard Andersen, 1997; Osborne and Cunliffe, 2005). Mediterranean urbanization, it was thus proposed, should be seen as a complex process of social, economic and political transformation in which two parallel dynamics are at work: state formation and settlement nucleation.

The adoption of new methods in archaeology in the late 1950 s and 1960s, in which fields are walked systematically to record ceramic distributions, has revolutionized the study of Ancient Cities. Both in Greece and in Italy, settlement systems began to be studied in a regional perspective, which allowed to distinguish settlement hierarchies and transformations of settlement systems through time (Ward Perkins, 1961; Bintliff, 1999, 2000, 2002, 2006, 2016; Stoddart, 1999; Peroni, 2000; Pacciarelli, 2001; Bintliff et al., 2017). Urbanization came to be studied from a long-term perspective and within a broader framework of ancient landscapes.

An important consequence of this long-term perspective in Italy was, moreover, the realization that the earliest urbanization predated the appearance of Greek cities on the coasts of Southern Italy and Sicily. Up until recently, scholars had heavily debated the role that the urban culture of the Greeks and Phoenicians had on Italian societies, particularly on Rome and the Etruscans (Peroni, 2000; Riva and Vella, 2006; Riva, 2010; Fulminante, 2014; d'Agostino and Gastaldi, 2016). But the roots of Italian urbanization seem to be firmly placed in the Final Bronze Age transition to the Early Iron Age-the eleventh/tenth centuries BC (di Gennaro, 1986; Guidi, 1998; Peroni, 2000; Pacciarelli, 2001; Fulminante, 2014).

One of the major challenges in studying urbanization in Italy is the lack of physical remains of the earliest cities. They lie buried under moderns cities or have suffered significant destruction throughout the millennia. Intensive archaeological analysis, including the collection of ceramics from the surface and excavations, have resulted in a general understanding of the spatial development of the earliest urbanization processes. In Central Italy, dispersed pottery scatters have been documented on large plateaus (from $20-30$ ha up to 80 ha), where the later Etruscan and Latin cities were located (Pacciarelli, 2001). Initially, the pottery scatters were seen as belonging to preurban, small and distinct, settlement nuclei, that after ca. two centuries came together in a process of aggregation (synoicism), to form an urban settlement (Ward Perkins, 1961). This process of aggregation has often been attributed to historically known hero-founders such as Romulus in Rome or Theseus in Athens. Even though steeped in legend, many scholars today still believe that there is a ground of truth in these founder-figures (Carandini, 2018).

Around the plateaus on which the settlements were located, burials plots have also been found (Pacciarelli, 2001; Fulminante, 2014). Initially, these were seen as belonging to the pottery scatters on the plateaus, i.e., separate nuclei (Ward Perkins, 1961). Now, it is believed that the settlement nuclei, including burial plots, were more integrated than previously thought. Consequently, it was suggested that the different burial plots might rather belong to different social classes, political groups or other social divisions within society (Fulminante, 2014, p. 8-9).

The short physical distance between the settlement nuclei means that arrangements, e.g., about the use of space, field boundaries, etc., must have existed before the settlement was fully centralized. The development of the state and urbanization thus, must have been one of transformation of power and the use of space, i.e., integration and centralization over time, rather than a sudden event and radical transformation in terms of a foundation ex nihilo.

The last decades, archaeologists have focused on diverging trajectories of urbanization and the underlying social and economic transformations that may have caused settlement centralization (Damgaard Andersen, 1997; Nijboer, 1997; Pacciarelli, 2001; Osborne and Cunliffe, 2005; Motta and Terrenato, 2006; Guidi, 2008; Fulminante, 2014; Bintliff, 2016; Fernandez-Götz and Krausse, 2016). The establishment of cities is thought to have coincided with the consolidation of the state, although that centralized power can exist without a centralized settlement (Morgan, 2003; Osborne, 2005). Especially in Greece the phenomenon of non-urban centralization through federations or ethne has been well-studied (Morgan, 2003).

In Italy, the appearance of nucleated and centralized settlements, early "cities," coincides with a marked rise of wealth deposited in tombs. It is thought that these tombs belong to a ruling "princely class" which consolidated its power and justified its position by adopting a new funerary ideology (d'Agostino, 
1968; Pacciarelli, 2001; Cuozzo, 2003; Fulminante, 2003; Riva, 2010; d'Agostino and Gastaldi, 2012, 2016; Pellegrino, 2015). How exactly these new elites exercised their power and came to be at the head of their communities is still unclear. The question as to why exactly the new state needed settlement centralization has also not yet been satisfactorily answered. Elite interaction with the Greeks and the accumulation of exotic objects could have been one strategy, but again, this explanation resorts to the "Greeks" as an explanatory factor in urbanization.

Thus, even though the general outlines of the urbanization process in Italy appear to be well-defined, several questions remain only partially answered. The mechanisms of the development of social and economic power underlying the urbanization process are still not well-understood. Yoffee sees state formation as a process of social differentiation and integration of the groups in a political framework (Yoffee, 2005). The way to understand early states, according to Yoffee, is by looking at interactions and tensions between different social groups and their leaders. Yoffee also points out that the interaction processes are complex and are not controlled by a single mechanism.

Yoffee himself rejects the possibility to model state formation processes mathematically, precisely for this reason of complexity (Yoffee, 2005, p. 169). However, as the present paper aims to demonstrate, a network-based exploratory approach is most appropriate to study early state formation and urbanization. Exploratory network analysis operates with a model to analyze complex datasets and, thus, provides a bottom-up approach to explore real-world data. The model is fairly simple and deeply embedded in social theory. Rather than taking an a priori emergent property at its core, the analysis tries to reveal markers of a process of diversification. The suspected complexity of the processes necessitate such a basic model.

Indeed, as Yoffee and others (Pacciarelli, 2001; Vanzetti, 2002; Fulminante, 2014) point out, the rise of the earliest cities was accompanied by social tensions and differentiation processes. The lack of written sources and the fragmentary archaeological data make that we have no information about the development of state power and elite agency in Ancient Italy. Inequality in this period seems to have been expressed in an archaeologically visible way in burial. Burial was in this time one of the main-if not the main-contexts for the creation of memory, the construction of social and economic differences and the negotiation of political power (Cuozzo, 2003; Fulminante, 2003; Laneri, 2007). We are unaware of the existence of other contexts in which inequality and power were expressed, e.g., sumptuous living, luxury dress or the consumption of exclusive food and drink, ritual activity. These contexts should not be excluded, but remain, at present, archaeologically understudied for the region and period in question.

Analyzing burials is, therefore, the key to studying the social tensions that scholars identify as underlying state formation processes, and ultimately, urbanization. Studying burials and social differentiation is, however, complex, because of the large quantities of data involved (Fulminante, 2003; Nizzo, 2015). From the well-studied early urbanizing communities throughout Italy, come hundreds, sometimes even thousands of tombs.
Quantitative methods, combined with qualitative analysis, are therefore, of fundamental importance for the study of burials.

One of our best known sequences of burials of an early urbanizing community from Iron Age Italy comes from the South Italian city of Pontecagnano (Figure 1). Even though more fragmentary for some stages, Pontecagnano provides an exceptional source of information, not in the least for its extensive and detailed state of publication. With some notable exceptions for the later eighth and seventh centuries BC (Cuozzo, 2003), past research on the burials at Pontecagnano has been qualitative, rather than quantitative. Pontecagnano is thus particularly suited for the testing of an analytical model geared toward studying the social dynamics that underlie urbanization.

The analysis of burial data described in the next paragraphs demonstrates that, in contrast to what qualitative analysis often seems to suggest, the expression of social differentiation in burial in the urbanizing communities in Italy was not a linear process moving from simple to complex. Variations in Cohesion metrics over time point out that, at times when there was less quantity in objects deposited in tombs, special effort was placed on quality (diversity e.g., exclusive and exotic objects, or new spatial manipulations). With the use of a model it is possible to identify these phases of expansion and contraction, a process which is highly indicative of social tension between different interest groups in society. A regulatory body, reminiscent of an early state invested with politico-religious power must have been in place to oversee the burial process, i.e., the creation of social memory and the exercising of power through the expression of status and wealth.

The model also enables to focus on more detailed aspects. The study of the circulation of selected objects through Network Centrality values provides an insight in strategies of manipulation of resources by elites. The most important trend that the analysis picked up is the increasing role of storage vessels in the tombs at the time of supposed settlement centralization. Collection and storage necessitate a certain level of control over the population and an appropriate infrastructure. The collection and storage of agricultural surpluses are therefore well-known as one of the main drives behind centralization and urbanization, and indicative of what the sociologist Mann (1984) calls increased "infrastructural power" of the state. The increased emphasis on storage vessels in burial is highly suggestive for a rise in importance of the collection and storage of agricultural surpluses in real life, as burial appears to have been the arena where status and display were increasingly played out (Cuozzo, 2003; Fulminante, 2003). The study thus proposes that, at Pontecagnano, collection and storage of agricultural surpluses was an important factor in urbanization.

\section{MODELING ANCIENT CITIES}

In contrast to modern cities, Ancient Cities have not received an overwhelming attention from a modeling perspective. Archaeological approaches to the earliest cities are very often merely descriptive, aiming at the classification of objects and structures in terms of type and chronology, or, at locating the 


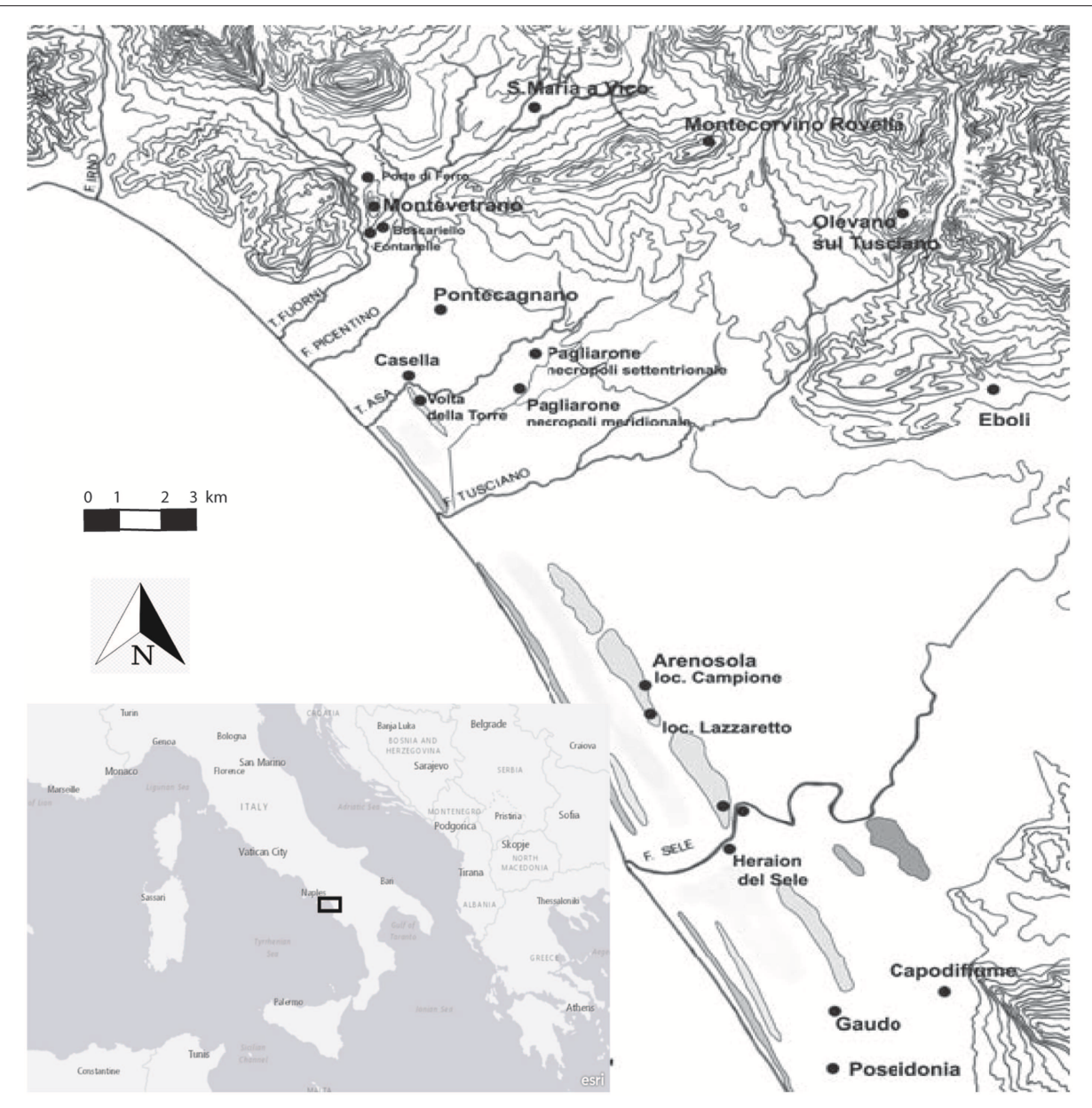

FIGURE 1 | Map with the location of the area of study within its local geographical context, including the burial plots of Pagliarone and Casella (adapted from Cerchiai et al., 2013, p.88).

remains of buildings on a map. Whereas, typo-chronologies can be very useful as a collecting strategy, they do not provide solid explanatory frameworks. Often, the use of typo-chronologies results in outdated culture-historical narratives and a reliance on much later written sources. Yet, there is a huge potential for studying ancient cities with computed models. Modeling allows to propose hypothetical reconstructions of fragmentary data, it contributes toward testing hypotheses and enables the discovery of patterns in large and complex datasets. Surprisingly, archaeologists have not adopted modeling approaches on a wide scale, despite the many advantages it may offer in complementing qualitative archaeological analysis. Models, such as the one used for the analysis in the present paper, need not be overly complex and can be heavily theoretically informed, yet very powerful as a heuristic tool.

Since decades, archaeologists have used modeling for all kinds of different questions, usually to study space, e.g., models for predicting settlement location (Bevan and Lake, 2013; Verhagen, 2018). Other models have focused on estimating settlement boundaries, e.g., with the XTENT model (Ducke and Kroefges, 2008), or explored the exploitation of ancient territories (Farinetti, 2009). Fruitful modeling has been applied to inter-visibility (Brughmans and Brandes, 2017) and the reconstruction of ancient transportation networks (Groenhuijzen and Verhagen, 2017).

Recently, modeling approaches have yielded positive results in the study of urbanization in Central Italy between the Bronze and Iron Age. In a series of studies Francesca Fulminante (2012a,b, 2014) (Fulminante et al., 2017) applied a network model to test various hypotheses regarding the formation of urban centers. By looking at settlements, locations and hierarchies as a network system, she formulated and tested a number of hypotheses regarding growth. One of the most striking conclusions that came out of the studies was the existence of regional differentiation in urban growth. In the region of Latium Vetus (later: Rome) the rich-get-richer effect seems to have subtracted increasingly people and resources from the surrounding area (Fulminante and Stoddart, 2010, 2012; Fulminante, 2012a,b, 2014).

The latter, as well as some other studies (di Gennaro, 1982; Guidi, 1985; Redhouse and Stoddart, 2011), rely on spatially determined models of urban settlement or growth (Gottdiener et al., 2005; p. 83-86; Li and Gong, 2016). Spatially-oriented views 
allow to formulate hypotheses regarding the underlying social, political and economic dynamics at a macro level. These are extremely useful to develop broad historical reconstructions in the absence of written sources. More challenging with a modeling approach, however, is the study of dynamics at a micro or meso level. Usually, archaeologists take settlements and regions as unit of analysis, and operate with datasets that, in fact, span centuries. With such an approach, it is difficult to obtain a finer chronological resolution or address agency. It is precisely here that an exploratory network approach, such as the one introduced in the present study, proves its utility: it uses elaborate datasets and a model developed to study human interaction at a meso level.

Recent advances made in adopting and adapting networktheoretic approaches in archaeology (Brughmans, 2010, 2012a,b; Knappett, 2011, 2013; Leidwanger et al., 2014; Collar et al., 2015), have enabled a whole new perspective on past human interaction. Following general trends in modeling in archaeology outlined earlier, the first examples of network analysis by archaeologists can be characterized first and foremost as spatial in nature. The previously cited studies of transportation networks (Groenhuijzen and Verhagen, 2017), visibility networks (Brughmans and Brandes, 2017), fall into this group, as well as studies of spatial organization of territories (Rivers et al., 2013a,b), or regional exchange systems (Mills et al., 2013, 2015).

Recent studies have applied network analysis to look at processes of social and cultural interaction and transformation such as the rise of ethnic identities (Collar, 2013; Blake, 2014; Peeples, 2018), to trace the diffusion of knowledge among artisans (Östborn and Gerding, 2015), or to study pottery production processes (Van Oyen, 2016). Most studies, however, depart from a site or region as unit of analysis. This scale of analysis is sometimes considered problematic for the perceived lack of agency (Knappett, 2011; Leidwanger et al., 2014; Collar et al., 2015; Van Oyen, 2016, 2017). Archaeological applications of network methods and theories yield, however, the potential to develop into a theoretically-enhanced approach to past materialized interaction (Donnellan, 2016a,b).

Focusing on communities of interaction may provide a fruitful path to explore the intersection between the social and spatial aspects of interaction at different scales (Peeples, 2018). Recent archaeological studies have devoted extensive attention to the study of communities and agency (Canuto and Yaeger, 2000; Mac Sweeney, 2011; Varien and Potter, 2011). The concept of "communities" also offers a firm theoretical foundation for the present analysis, as "communities" are a key concept in contemporary urban studies. The study of community formation and transformation within urbanizing processes are at the heart of urban sociological and geographical analysis (Gottdiener et al., 2005). The notion of "community" relates to Yoffee's idea of archaeologically detectable social groups and their differentiation as basis for state formation (Yoffee, 2005). Moreover, community detection constitutes one of the corner stones of formal network analysis (Boissevan and Mitchell, 1973; Boissevan, 1979; Wellman and Berkowitz, 1988; Wasserman and Faust, 1994; Borgatti et al., 2013). The concept of communities thus allows to connect to a broad range of theoretical and methodological approaches.

Community detection was also at the heart of the study made by the sociologist Davis and his colleagues about race relations in the Deep South of the US (Davis et al., 1941). They studied the norms and behaviors that sustained the construction of racial and social identities among different groups of people. One of the groups of people they studied was a small group of upper class women that attended high society events. Based on the frequency of co-attendance of these events, Davis et al. concluded that these women formed subgroups or cliques. By interacting frequently on the occasion of the events, these women developed similar patterns of behavior and expectations. One of the central notions of network analysis is exactly this similarity in behavior of agents, "homophily" (Carrington and Scott, 2011; Borgatti et al., 2013). The tighter the network, the greater the similarity between actors. Innovations within the network, according to network theory, come from interactions with actors outside the closelyknit group, as the concepts of weak ties (Granovetter, 1973) and structural holes (Burt, 1995) indicate.

The Davis study is considered a "classic" example in formal network theory for the two mode model (Borgatti et al., 2013), despite the fact that Davis and his colleagues did not use formal network analysis, nor developed the well-known graphical representation with nodes and ties. The visual representation of social networks, the sociogram, had been developed a decade earlier by Moreno (1934), but was not yet applied widely at the time of the Davis study. Davis and his colleagues used a matrix to represent the frequency of attendance of the social events by the group of women (Figure 2).

As Davis demonstrated, focusing on similarities such as coattendance of events is the key in detecting communities of interaction. Similar principles for community detection have been applied to study the network of intermarriage and business among the Florentine elite in the Renaissance period (Padgett and Ansell, 1993) and the notion of interlocking boards of directors (Mizruchi and Schwartz, 1992). In reality, all two mode network analysis takes this idea of interaction and community formation as starting point. The model and its theoretical foundation were therefore considered to provide a solid theoretical and methodological base and thus adapted to fit the question of community interaction and diversification at Pontecagnano.

In contrast to sociologists and historians, archaeologists do not have access to information regarding the attendance of events, intermarriage or business ties. However, archaeologists can focus on the material remains of interaction. Building styles, pottery production styles, burial rites, etc., present similarities and differences in production, appearance, and consumption and can thus be indicative of close interaction. Similarities in behavior, called "homophily" in sociology (McPherson et al., 2001), can be voluntarily or coerced, but is essentially present in one way or another in cliques or network clusters. Even though the original process of tie formation, e.g., co-attendance, marriage, or business cannot be detected by archaeologists, similarities in the material world can act as a proxy for social interaction and can be studied in terms of markers of community formation. Even though fragmentary in nature-called the black 


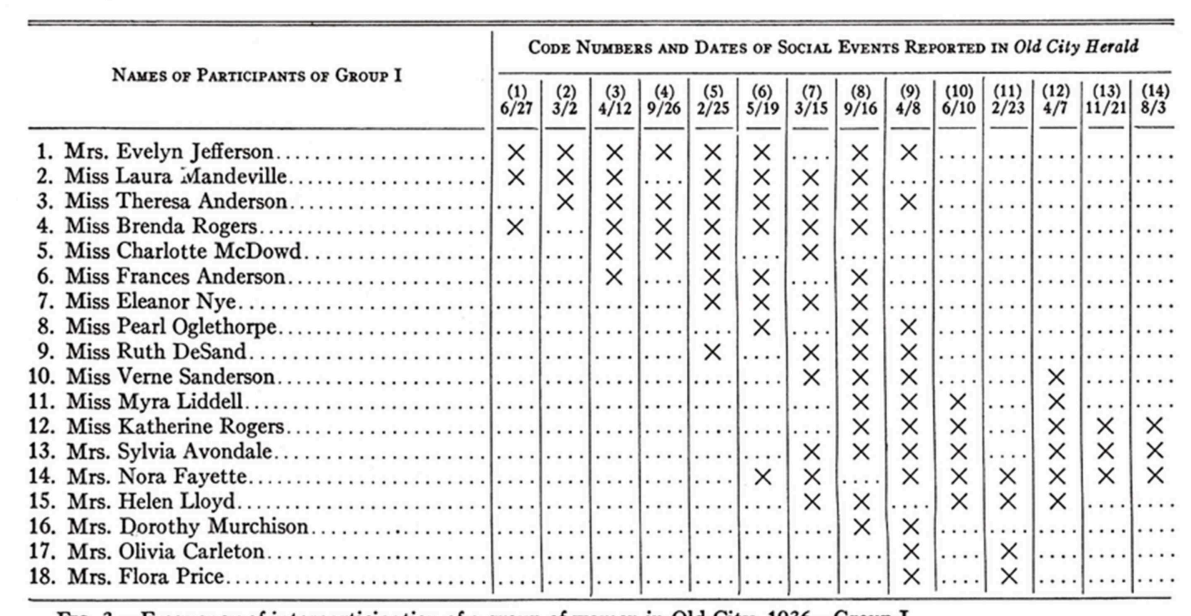

FIG. 3.-Frequency of interparticipation of a group of women in Old City, 1936-Group I.

FIGURE 2 | Matrix to link women to events they attended, used by Davis and his collaborators (from Davis et al., 1941, p. 139).

box problem-general trends of community formation can indeed be detected in archaeological datasets (Sindbæk, 2013).

Obviously, not all close interaction results in material similarities, nor does material similarity necessarily indicate close interaction, as it can be simply a coincidence. Key is to relate the material record to identifiable social behavior and contexts of interaction. The way an archaeological interaction model thus operates is by documenting all material features in the archaeological record that relate to identifiable depositional practices, e.g., burial. This materialized dataset of coherent behaviors, in its entirety, constitutes a network. Ties between features are next created when the features share similarities, following the principle of the two mode model. The more ties, the closer the similarities and the more important the homophily between the agents.

In reality, there are several ways of constructing a model. For the model in the present paper, the two mode model of Davis was followed closely and adapted to the specific research question: Davis' women are "translated" into tombs and the events into the material features of the burial (Figure 3). The material features are considered a proxy for the event: the whole series of gestures, vocal expressions, movements, and perishable objects, etc., that were used in burial (Nizzo, 2016). The key assumption is that similarities in material expression are indicative of close community interaction (be it voluntarily or coerced), and dissimilarities are evidence of diversification. The diversification processes, thought to underlie state formation as outlined supra, can thus be studied with what is, essentially, a similarity matrix.

The model-a standard two mode network model—can be manipulated for analysis using a number of algorithms (Borgatti and Everett, 1997; Opsahl, 2013). These analytical tools are included in several standard consumer software programs for network analysis, such as UCINet (Borgatti et al., 2002), which was also used for the analysis reported in this paper. There are many analytical procedures available. Relevant for the case study are: Cohesion and Centrality, whose definition and analysis are reported below.

\section{THE CASE STUDY}

\section{Background}

Pontecagnano is a well-known archaeological site, located in the region of Campania, province of Salerno, in Southern Italy and was one of the most important Southern Etruscan cities, whose name, however, is not known with any certainty. In $268 \mathrm{BC}$, the Romans re-founded the city as Picentia.

Emergency excavations in the context of large-scale infrastructural works were conducted by the local archaeological services from the 1960s onwards, with important contributions from the University of Salerno for the study and publication of the results. These excavations resulted in the discovery of various nuclei of tombs, located east and west of the city, as well as traces of urban architecture, mostly of later date (d'Agostino, 1968; Cuozzo, 2003; Cuozzo et al., 2004; Bonaudo et al., 2009; d'Agostino and Gastaldi, 2012, 2016; Pellegrino, 2015). The excavations allowed to propose a hypothetical reconstruction of the regular lay-out of the Roman city, which apparently overlays the earlier Etruscan city. The topography of the earlier phases is only known in part, however, the general spatial development of the settlement through time has been reconstructed (Figure 4).

The earliest remains that testify to human occupation are burials in the areas of Pagliarone (Gastaldi, 1998) and Picentino (d'Agostino and Gastaldi, 1988; Cinquantaquattro, 2001; De Natale, 2016), dated to the early ninth century BC. Through time, new plots were taken into use at San Antonio, in the later ninth century BC (De Natale, 1992). The Pagliarone plot does not offer extensive evidence beyond the earlier phases, whereas the other plots continued to be used for many generations. At the turn of the eighth to seventh centuries BC, there is evidence for an extensive reorganization of the funerary landscape, with new plots taken into use, e.g., at the Piazza Risorgimento (d'Agostino, 


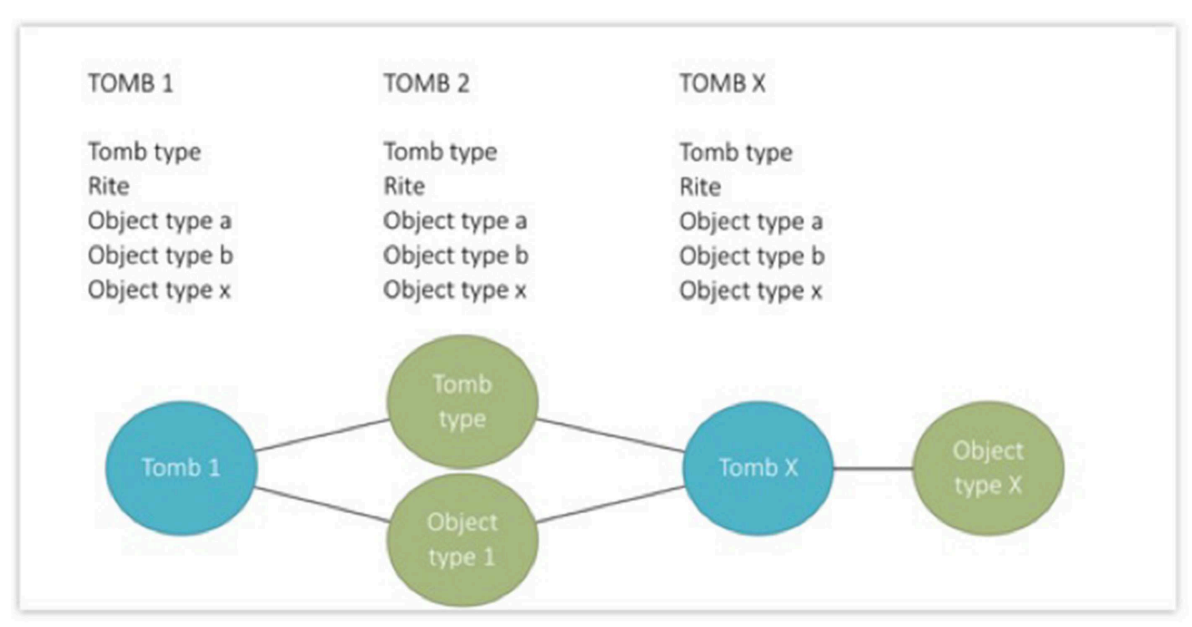

FIGURE 3 | Visual representation of the two mode model used in the analysis, based on the graph representation of a standard two mode network.

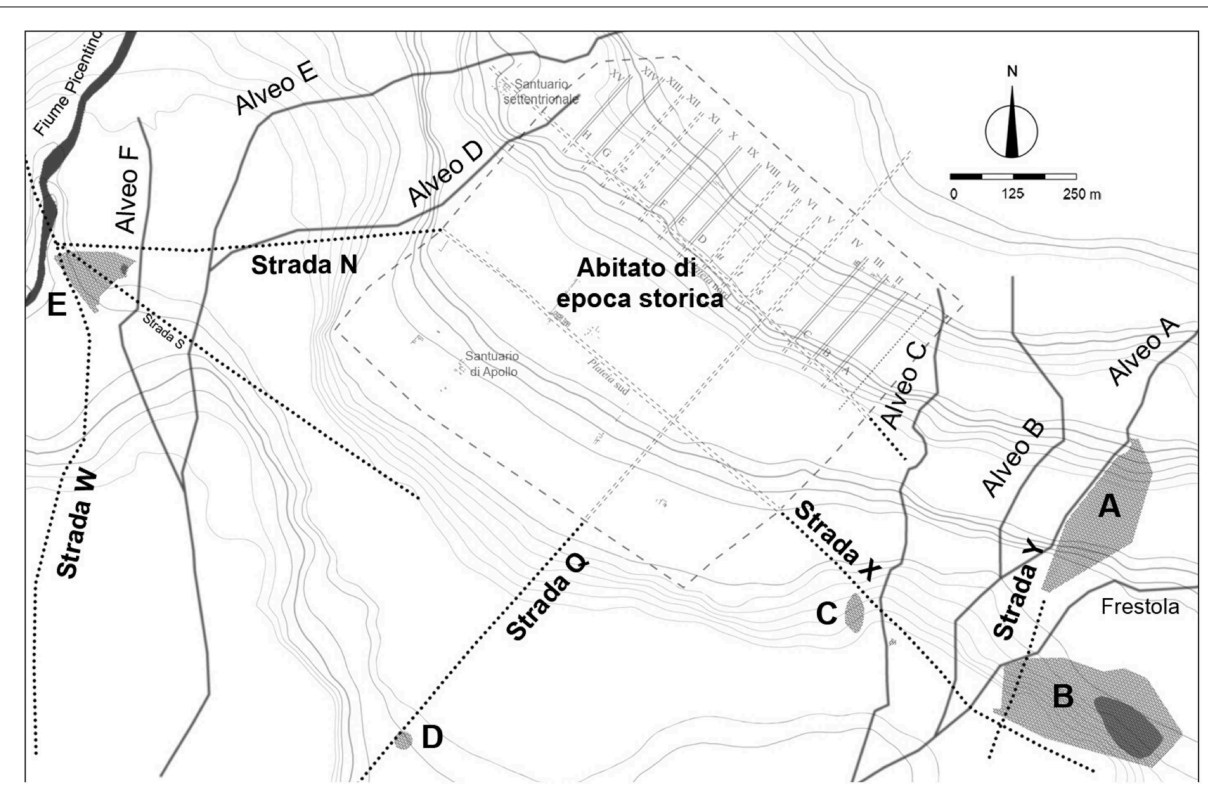

FIGURE 4 | Reconstructed spatial development of Pontecagnano between ca. 900 BC-Roman Period: A-B-C: S. Antonio burial plots, D: South necropolis, E Picentino burial plot. Center: "abitato di epoch storica": historical city center with reconstructed street pattern (from d'Agostino and Gastaldi, 2016, p. 160).

1968), whereas other plots such as on the contemporary Corso Italia (Cerchiai, 1987) or the plot of Casella (Cinquantaquattro, 2001) testify to new extensions to existing burial grounds. These reorganizations are considered to be the hallmark of the early urban community (d'Agostino, 1968; Cuozzo, 2003; Cuozzo et al., 2004; Bonaudo et al., 2009; d'Agostino and Gastaldi, 2012, 2016; Pellegrino, 2015).

Between the various plots and through time, there is a marked variation in burial practices that testify to the existence of dynamic communities and interaction, which will be the object of the analysis. The burials consist of simple pit burials for inhumation (a fossa) or for cremation (a pozzo). Slightly more elaborate architectural shapes exist already for inhumation, with the bottom, walls and cover dressed with stones (Figure 5). Cremated remains could be deposited in a pit, covered with a large stone (a ricettacolo), sometimes elaborated with a sort of platform on which objects could be displayed (a vestibolo). The typical way of depositing cremated remains, in a biconical urn covered with a one-handled bowl, or sometimes a ceramic helmet, echoes the practices known in Central Etruria, in the area of the so-called Villanova groups, considered the predecessors of the Etruscans (Bartoloni, 1989).

On the occasion of the burial, various objects were deposited simultaneously with the remains of the deceased. These objects 


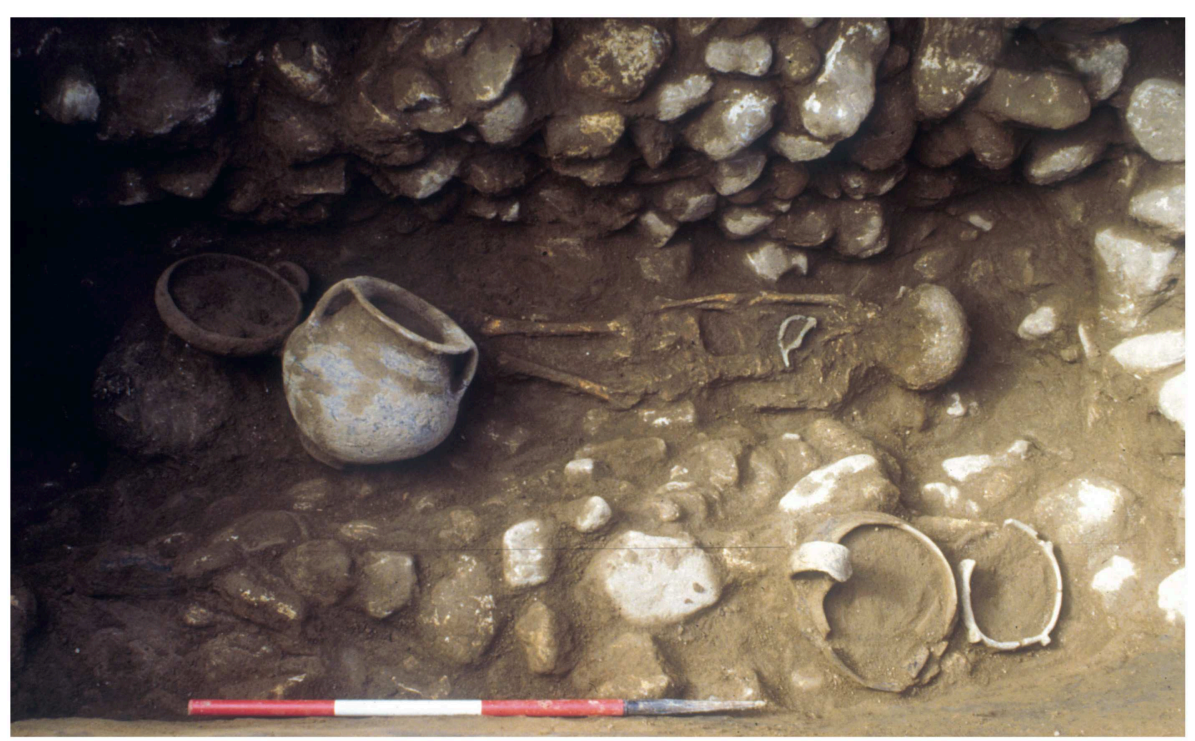

FIGURE 5 | Inhumation tomb 6473 "a fossa" (phase IIA) at the time of excavation, with an amphora, two bowls, cups, attingitoio, fibula, spindle whorl and bronze fitting [from: (De Natale, 2016). Pontecagnano II.7. La necropoli del Picentino. Tombe della Prima Età del Ferro dalla proprietà Colucci. Naples: Istituto Universitario Orientale, p. 68 fig. 26].

could range from a variety of ceramic containers for the consumption of food or drinks, for pouring or storage (anfora, anforiscos, askos, piatto, scodella/-one, tazza, and other shapes), items for dress and bodily care and adornment (fibulae, rings, clasps, razors, etc.), equipment for weaving and a variety of weapons.

The material culture at Pontecagnano has been the object of sustained study by archaeologists, and as a result, our knowledge of the typological variety of the local material culture is decidedly among the best in the whole of Italy for this period (Gastaldi, 2016). Not all contexts have been published yet and several plots are still in course of analysis. Most importantly, the vast majority of the tombs of the so-called Orientalizing period (late eighth to seventh centuries BC) are currently still in course of study. The future publication of new information will provide an opportunity to test the hypotheses formulated in this paper. Some plots have been published, such as at the Piazza Risorgimento (d'Agostino, 1968), Corso Italia (Cerchiai, 1987), as well as in the above-mentioned burial sites of Picentino at Località Casella (Cinquantaquattro, 2001) and San Antonio (De Natale, 1992), but some plots during certain time intervals have given evidence of only one or two burials (S. Antonio I-IB; Piazza Risorgimento; Corso Italia). These plots have not been included in the quantification as network analysis does not function well with very small amounts of data. Future analysis could focus on the integration of the different datasets into one larger dataset, including the material that is still being studied.

Importantly, a study by Cuozzo (2003) has dedicated ample attention to the unpublished Orientalizing tombs and reconstructed the social and political transformations of the period. Cuozzo applied a cluster analysis to trace the dramatic increase in social differentiation in the late eighth and the seventh centuries BC. Social differentiation was much less pronounced in the earlier Early Iron Age phases, and Cuozzo explained the phenomenon as a conscious strategy to support an ideology of power, carved out by a new, urban, political elite. Part of the elite strategy was a transformation in the use of space through the relocation of burial and settlement centralization. Cuozzo's study has been particularly important for providing tangible evidence for socio-political dynamics underlying the general patterns of urbanization identified in other Central-Italian centers.

However, as was explained previously, despite the major achievements of existing studies, several questions remain unanswered. The earlier phases at Pontecagnano remain understudied in quantitative terms and a quantitative comparative analysis of the different plots, all published in different volumes, has not been undertaken. It was outlined supra that the exact mechanisms of integration of the various nuclei into a single urban community are not described in detail and the diversification of the community within the process of state formation has also not been defined in detail. By using a two mode model, or similarity matrix, the analysis discussed below aims at describing the diversification process in more detail.

\section{Analysis of the Case Study Datasets}

As a first step, the analysis started with manually digitizing the data of published archaeological contexts (tombs). The dataset was collected and stored in Access to allow an easy extraction to compile datasets in the UCINet format. The information collected in the database concerned material, shape, type, date and context of objects and rite, tomb shape, date, and location for context. Additional information such as orientation, gender, age was collected for tombs as well. Detailed typological 
classifications of the objects as defined by the excavators (Gastaldi, 2016) were also inserted in the database although the present study will not take this level of detail into consideration. The focus lies on object shapes, e.g., cup, bowl, or fibula, etc. A study of the circulation of the detailed object typochronology defined by the excavators would, no doubt, reveal new dynamics, but this would ideally be undertaken together with an archaeometric analysis, as typological classification does not necessarily coincide with production units. An analysis purely based on typological units would thus, not necessarily provide all the details one would, ideally, wish for.

An issue in the analysis is certainly the integrity of the data, as not all tombs are well-preserved. Some tombs were destroyed already in Antiquity, others more recently. Tombs or objects that were only partially preserved have been omitted from the analysis if they were beyond basic recognition, i.e., shape. Another issue is that not all tombs are well-dated. The analysis relies on the traditional chronological classification in phases. The tombs for which only a very broad chronological estimate could be given, e.g., a date within the whole "Early Iron Age" (which spans almost two centuries!), have also been omitted from the analysis. Tombs that have been dated tentatively to a chronological range, e.g., Early Iron Age I rather than phase IA or IB, have been included twice in the analysis, i.e., both in phase IA and IB.

There are obviously several ways to deal with impartial and fragmentary data in archaeological network analysis. Ideal would be to develop different approaches, varying from more detailed, omitting uncertainties, to broader, including the more fragmentary evidence. The various datasets could then be compared to assess which one provides the better results. However, limits posed to space in this paper do not allow such an elaboration, although future analysis should certainly aim to address the factor of uncertainty in a more elaborate way.

A series of datasets was compiled for every published burial nucleus, per time slice (chronological phase). Thus, datasets were developed for Picentino Phase I-IA (c. 900-850 BC), I-IB (c. 850780/70 BC), II-IIA (c. 780/70-750 BC), II-IIB (c. 750-730/20 BC), Pagliarone I-IA (c. 900-850 BC), I-IB (c. 850-780/70 BC), San Antonio II-IIA (c. 780/70-750 BC), II-IIB (c. 750-730/20 BC), c. 730/20-675 BC, c. 675-600 BC, and Loc. Casella c. 725-700 BC. The other plots with only one or two tombs were excluded as small numbers do not allow for network modeling, as was outlined supra. The results reported below were obtained via standard exploratory analysis of Cohesion and Centrality using UCINet (Borgatti et al., 2002).

\section{Cohesion}

Network cohesion can be understood as measure of how closely connected or tightly knit a network is, i.e., in this specific case study: how similar or dissimilar the burials are. Network cohesion can be calculated in virtually any network analysis software package, using standard algorithms. The calculation gives a relative value for the network as a whole (Borgatti et al., 2013): if everyone knows everyone, cohesion is 1.00 .

The cohesion measure includes the calculation of a number of elements (Borgatti et al., 2013), such as density or degree (the number of ties), and distance between the nodes: the minimum distance (radius), maximum distance (diameter) and average distance. Average distance indicates how many steps must be taken on average to arrive from a node to a randomly chosen other node, traveling via shortest paths (Borgatti et al., 2013). Diameter gives the longest of all shortest paths in the network, whereas radius is exactly the opposite, and gives the shortest of all paths (Borgatti et al., 2013). There are other measures to calculate cohesion, but these will not be discussed further within the context of this paper, as they do not provide any added value to the discussion.

The Cohesion metrics for the datasets have been calculated in UCINet and the results have been plotted in a graph, to enhance readability (Figure 6). The plot showing density (a) clearly shows variation in the density, i.e., the number of ties, or objects associated with tombs. It is often easily assumed that the diversification process that accompanied state formation and urbanization in Italy was a linear one, in which a group of people gradually deposited more and more objects in the tombs. The graph clearly shows that this was not the case and that the average quantity actually drops (phases I-IB and II-IIA in Picentino) before it rises again, in the S. Antonio and Casella plots after phase II-IIA.

The other Cohesion measures focus more on similarity and dissimilarity. The lower the distances between the nodes, the more similar the tombs were in terms of objects deposited. Radius provides a value for the minimum number of steps that have to be taken from one node to reach another (this would be calculated in terms of co-association of objects in the tombs: through co-association, one could virtually travel from one node to the other). Diameter gives a value for the maximum number of steps that have to be taken (again through the virtual steps of coassociation of objects in the tombs) and average distance provides the average value.

The patterns revealed by the graph are highly interesting as (1) they also do not show a linear development from more similarity to less similarity through time and (2) in conjunction with the values for degree, they clearly show the existence of tensions in the system.

A first rise in diameter can be observed in Picentino in phase II-IIA. This indicates that there is an increase in dissimilarity in terms of objects deposited in tombs (a larger variety of types). This trend is at odds with the low value for degree: at exactly the same time, we can observe the lowest degree value for the whole network. This suggests that, while people deposited fewer objects in the tombs, they sought out larger variation. This trend is highly suggestive for the existence of social tensions, and possibly, limits that had been enforced on the spending in burial rites: one could not deposit too many objects at the time of burial.

The other striking trend at S. Antonio for the same period reveals the opposite: people deposited more objects at the time of burial, but the objects were less diverse: the focus was on quantity rather than quality. Through time, this pattern continues to exist at S. Antonio: the number of objects deposited in the tombs increases, but there is not so much diversity. Again, this can be understood as a measure of reinforcing certain behaviors in burial, be it self-imposed or coerced, in which ostentatious depositing of wealth was not permitted. 


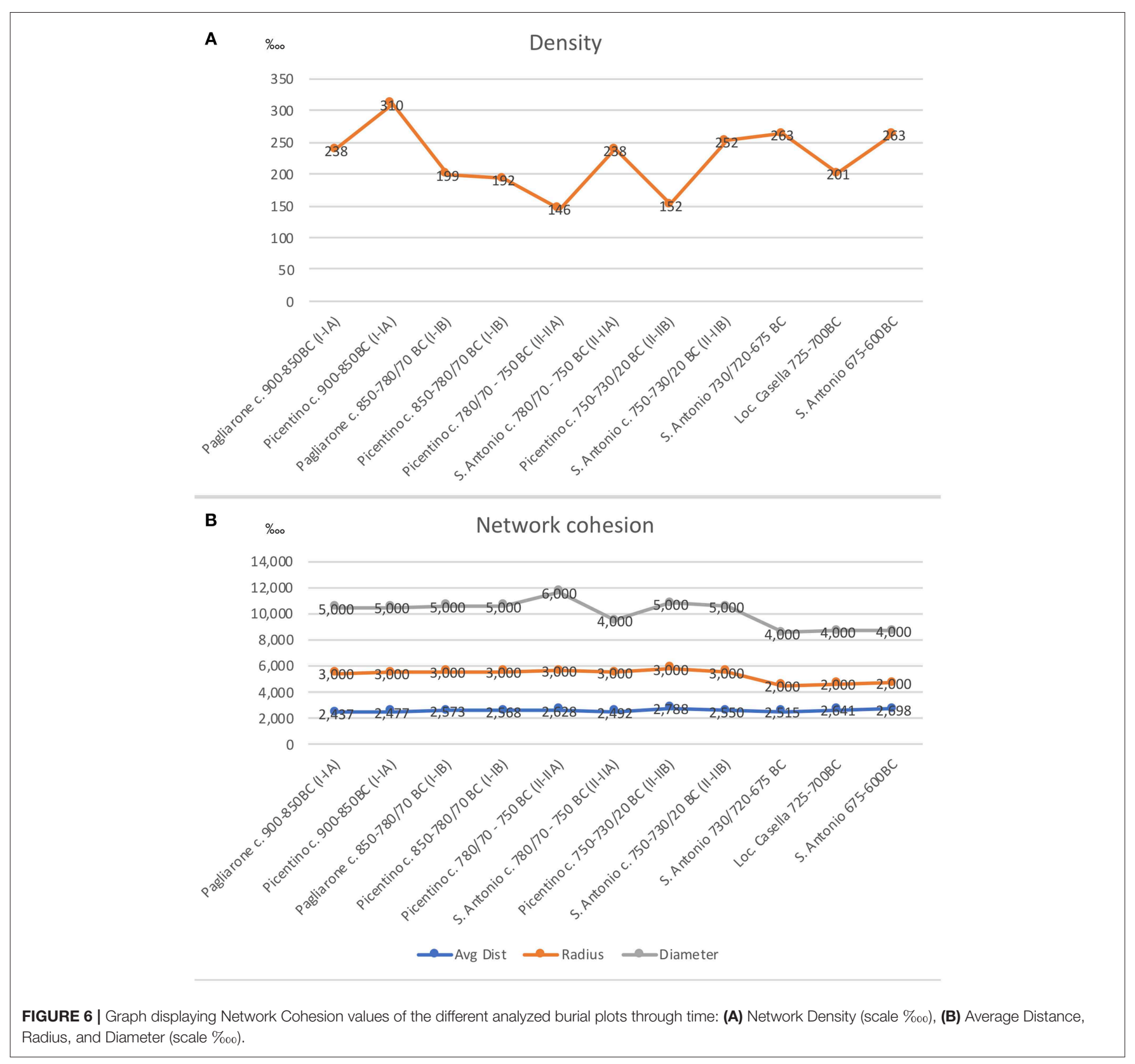

\section{Centrality}

A next series of measures that was performed on the datasets concern Centrality. Whereas, Cohesion looks at the network as a whole, Centrality operates at node level and assesses the degree of importance of a node within the network (Borgatti et al., 2013).

There are different ways to calculate Centrality. Degree Centrality is calculated based on the number of vertices incident to the node, i.e., the number of ties a node has. A variation of Degree Centrality is Eigenvector Centrality. This measure counts the number of nodes adjacent to a given node (just like Degree Centrality), but weights each adjacent node by its Centrality (Borgatti et al., 2013). Other measures of Centrality that can be calculated are Closeness, which is based on the sum of the geodesic distance (i.e., the length of the shortest path) from a node to all other nodes. Betweenness centrality indicates how often a given node falls along the shortest path between two other nodes (Borgatti et al., 2013). In terms of our model, a high Degree Centrality means that an object occurs frequently in the tombs, whereas the measures of Closeness Centrality and Betweenness Centrality indicate how often it is associated with other "popular" objects. This measure, in fact, looks to what extent a node can be considered part of the "norm" in funerary behavior at a specific time.

Because of limited space, the present paper focuses on describing the circulation of a selected number of objects via Centrality measures only. Future studies can focus on 
other material categories, as well as on individual tombs. The object groups whose circulation is discussed are: vessels for the consumption of food and drink (scodella and tazza), vessels for the pouring, consumption and possibly libation of liquids (askos, brocca, attingitoio), status objects (the fusaiola or spindle whorl for weaving equipment and weaponry such as the ceramic helmet or elmo fittile, lancia, spade, and giavelotto), objects for bodily adornment (fibula and bracciale), and storage vessels (olla and amphora). Obviously, the archaeological record has revealed many more objects, but the selected objects are some of the most frequently encountered and can be seen as representative for general trends in the community.

The graph (Figure 7) shows that both cups and bowls (tazza and scodella) enjoyed popularity during the earlier phases, but declined after ca. the mid-eighth century BC, both in quantity (Degree) and relative importance (Eigenvector, Closeness and Betweenness). The increasing popularity of Greek-style painted fine wares at Pontecagnano (not included in the graphs) can be seen as an explanation: the new style of vessels were probably considered to be more attractive and they could easily serve as substitutes for the plumper handmade vessels of the earlier local tradition.

Among other vessels for transferring liquids (from one container to another, or to the ground in an act of libation or for consumption), two types see a sharp decline through time: the askos and brocca see hardly or no use in the later phases, as the graph (Figure 8) shows. However, despite the steep decline in numbers of the askos (lower degree value), the Closeness Centrality in Picentino II-IIB is still high. This indicates that what we have was very much part of the core of the network, suggestive for high similarity with the other tombs and thus, normative behavior.

Interesting is the increasing popularity of the attingitoio, a larder-shaped vessel. Whereas, the other vessel types might have been abandoned for more appealing painted fine wares, the attingitoio appears to have continued in use, despite being plump, unpainted and handmade. A similar development was observed in another (unrelated to this) study in the North Aegean in the Iron Age, where pouring vessels deposited in burials continued to be handmade, despite the availability of wheel made fine ware alternatives (Donnellan, 2017). A possible

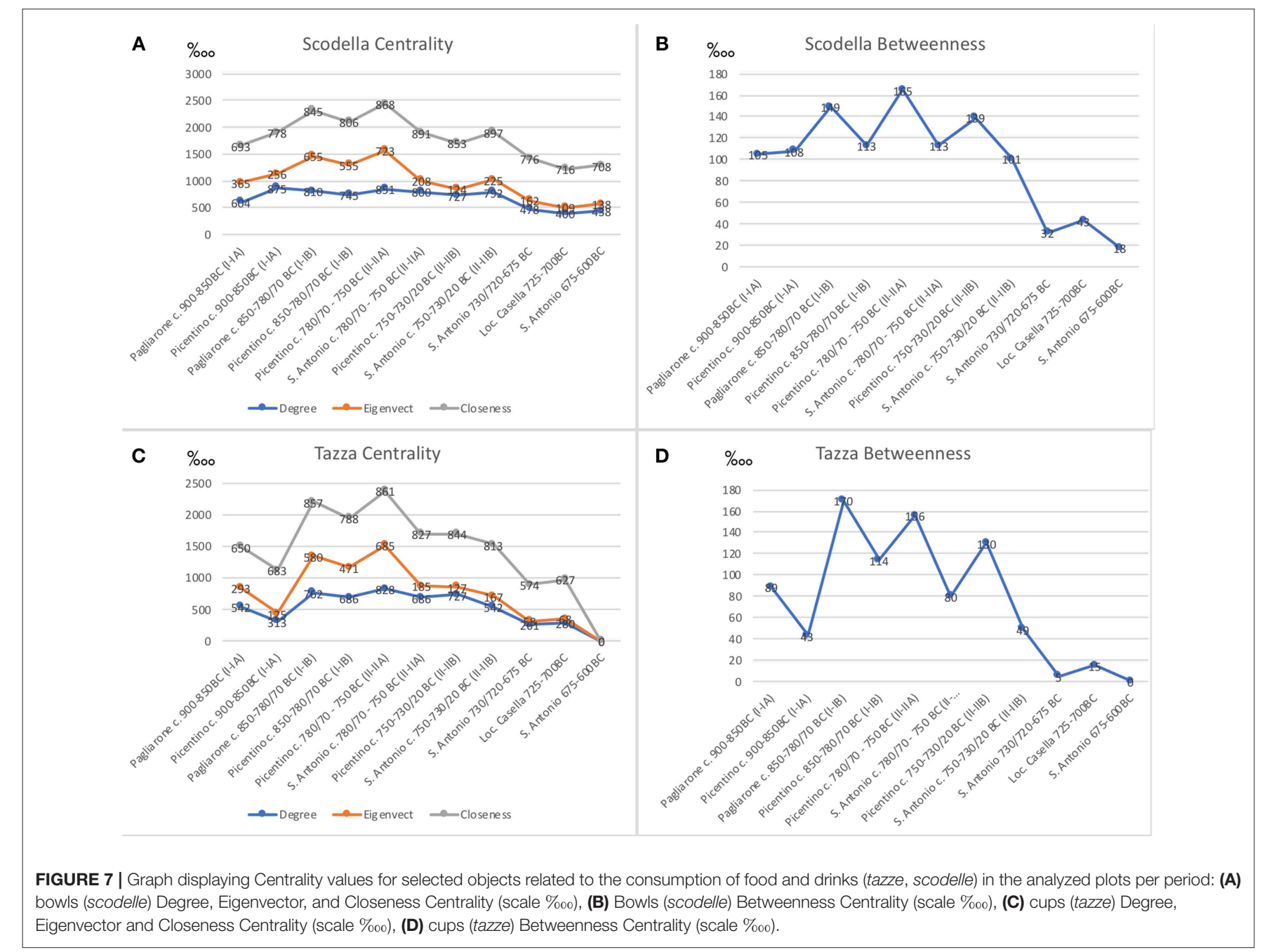



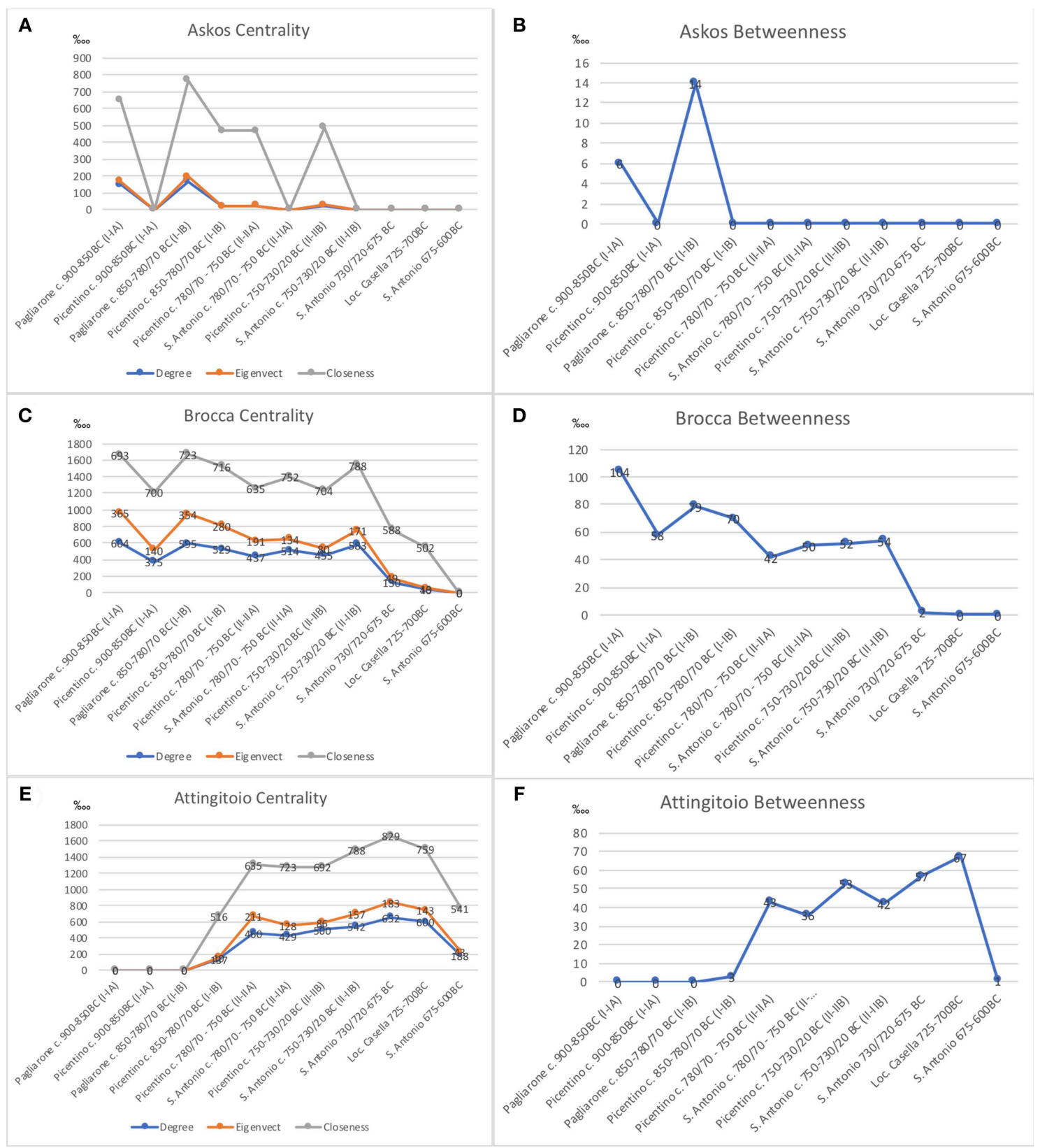

FIGURE 8 | Graph displaying Centrality values for selected objects related to transferring liquids (pouring/consumption): (A) askos Degree, Eigenvector, and Closeness Centrality (scale \%oo), (B) askos Betweenness Centrality (scale \%oo), (C) jug (brocca) Degree, Eigenvector, and Closeness Centrality (scale \%oo), (D) jug (brocca) Betweenness Centrality (scale \%oo), (E) larder (attingitoio) Degree, Eigenvector, and Closeness Centrality (scale \%oo), (F) larder (attingitoio) Betweenness Centrality (scale \%oo).

explanation in the Aegean case was that the production of the vessels was invested within special, possible ritual, significance in which the vessels were attributed agency, which made that the production and consumption prohibited the use of massproduced wheel made vessels. It can be hypothesized that the use of the attingitoio at Pontecagnano was attributed similar ritual agency, and therefore, the shape continued to be produced in a traditional way.
The graph looking at status objects (Figure 9) shows a decline through time for the spindle whorls (fusaiola). This is curious, as the role of textiles in the urbanization process has been underlined recently (Gleba, 2015). Despite the supposed importance of textile production and its aristocratic connotations, this was not expressed in the later tombs. Weaving was essentially a gender-related activity and it is possible that the expression of gender-related status was deemed less central in 

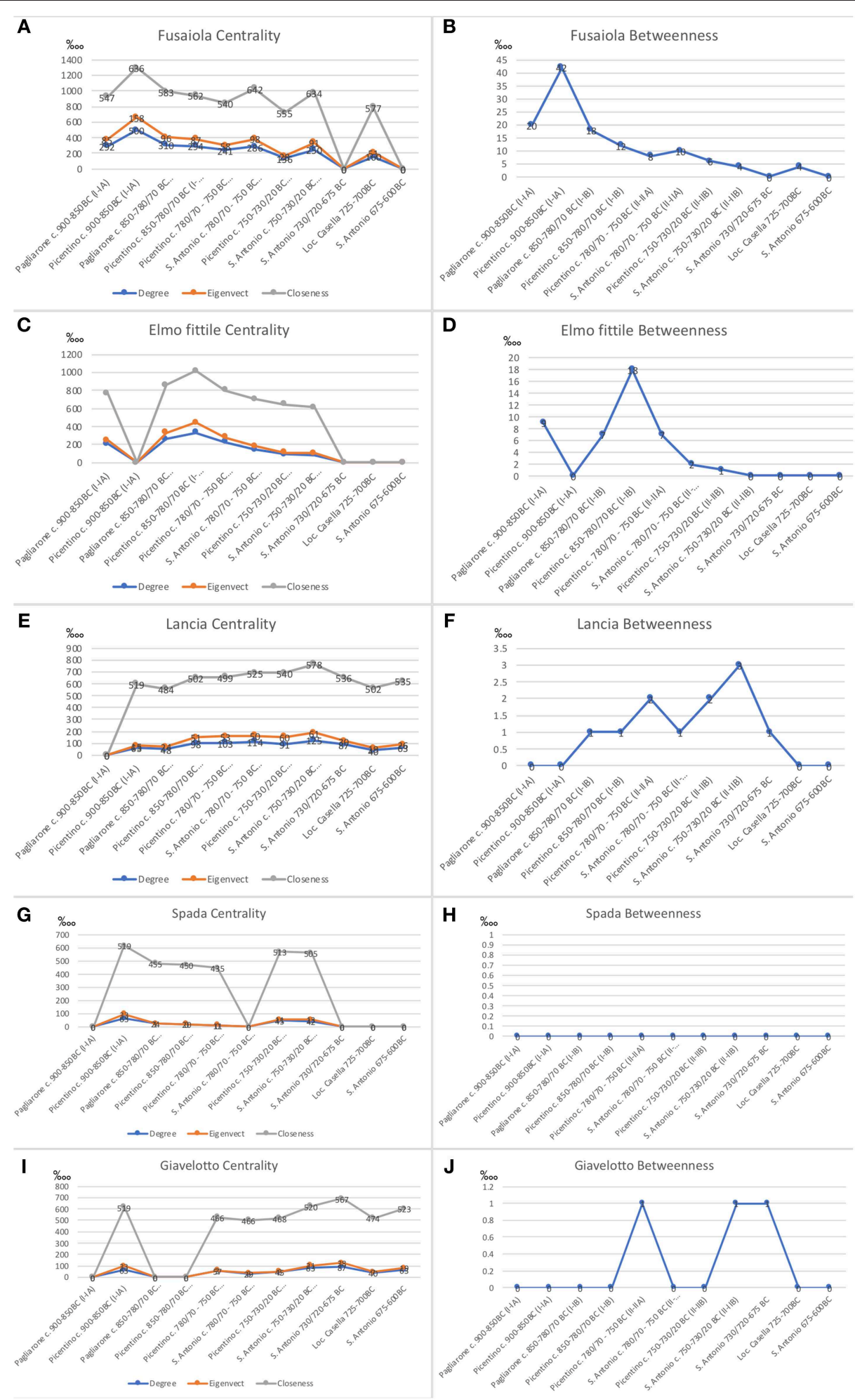

FIGURE 9 | Graph displaying Centrality values for selected objects related to status display: (A) spindle whorl (fusaiola) Degree, Eigenvector, and Closeness Centrality (scale \%oo), (B) spindle whorl (fusaiola) Betweenness Centrality (scale \%oo), (C) ceramic helmet (elmo fittile) Degree, Eigenvector, and Closeness Centrality (scale \%oo), (D) ceramic helmet (elmo fittile) Betweenness Centrality (scale \%oo), (E) lance (lancia) Degree, Eigenvector, and Closeness Centrality (scale \%oo), (F) lance (lancia) Betweenness Centrality (scale \%oo), (G) sword (spada) Degree, Eigenvector, and Closeness Centrality (scale \%oo), (H) sword (spada) Betweenness Centrality (scale \%oo), (I) spear (giavelotto) Degree, Eigenvector, and Closeness Centrality (scale \%oo), (J) spear (giavelotto) Betweenness Centrality (scale \%oo). 
burial at the time of intensified urbanization in the late eighth to seventh centuries BC.

Among the weapons, a decline can be observed in the graph (Figure 9) for the ceramic helmets and swords (elmo fittile and spada). The ceramic helmets served no purpose in daily life, but are considered imitations of real bronze helmets (Egg, 2017, p. 167). Possibly, these were part of traditional forms of expression of role and status, together with the sword, whereas the lances and spears (lancia and giavelotto) (Figure 9) remain fairly constant in use through time. Moreover, the high Closeness values of the latter seem to indicate that they continued to occupy a central position in the network. This can be understood as the integration of these items into new urban elite behaviors. Spears are associated with hoplite armor, which is considered an urban form of organization of community defense, attested also later in Etruria (Egg, 2017). Such an organization of military forces can thus be seen as a clear expression of organized state power and urbanization and also of effective state formation.

Among the metal objects for dress and bodily adornment, the analysis looked at fibulae and bracelets. A large variety of metal objects have been found in the tombs at Pontecagnano, but both selected objects types allow to document the general trends in the network. Given the advance of elite power through time, the analysis was particularly interested to see whether the general access to metal objects would be restricted to elites as they grew more powerful with the advent of state formation and urbanization. As the graph displaying the metrics shows (Figure 10), the circulation of fibulae remains fairly constant through time, in terms of Degree, Eigenvector, and Closeness Centrality. The Betweenness Centrality values (Figure 10) display more of a decline, however. Betweenness indicates the role a node plays as a bridge in the connection of other nodes. The decline in Betweenness Centrality in our model could indicate that the fibulae did indeed become a little more confined to a group of tombs that were more part of the core, i.e., similar in content. The patterns in the graph are, however, suggestive for the traditional patterns of redistribution of metals remaining intact through time, at least until the late seventh century BC, despite the major transformations at a political level and the advance of state formation and urbanization. The deposition of bracelets even displays an increase, as the graph indicates (Figure 10). This can be understood as part of the general trend in the seventh century $\mathrm{BC}$ of depositing more wealth in the tombs.

The last group of objects whose circulation this paper will discuss are storage vessels. Ollae and amphorae are common household vessels that were repurposed for burial. The graphs (Figure 11) indicate that, initially, they were not very popular in the tombs. However, the olla sees a steep rise especially from phase II-IIA onwards, to decline again toward the late eighth century BC. The shape is not abandoned fully and even becomes slightly more popular again in the seventh century BC. The decline of the ollae seems to coincide with the increase in popularity of the amphorae. These see a gradual rise initially, but the development is much more outspoken after ca. $750 \mathrm{BC}$. This is an important development both in terms of state formation and urbanization.

The increased emphasis on the depositing of amphorae in the tombs comes at a time that a local production of amphorae was established on the nearby island of Pithekoussai, with which Pontecagnano interacted intensively. The Pithekoussan amphorae are of an entirely different type, but were essentially storage vessels presumably for the local wine production (Donnellan, 2019). The Pithekoussan amphorae were often repurposed in the local necropolis, almost exclusively for infant burials. The intensification of the wine production at Pithekoussai and the facilities needed for production, collection and circulation are thought to have been an important factor in the local urbanization process (Donnellan, 2019). It is very tempting to see an analogous development at Pontecagnano, even though it is unclear which production the amphorae might have served. In contrast to Pithekoussai, the amphorae in the necropolis at Pontecagnano were not used for the burial of infants. They were much smaller and would have been more difficult to reuse in a similar way as at Pithekoussai. The ideology behind depositing storage vessels, however, can be considered the same: signaling agricultural wealth and abundance. In Athens, most famously, one had to produce at least 500 medimnoi (an ancient unit of volume) of grain to belong to the highest classes and obtain political rights (Arist. Ath. Pol. 7.3-4). The identification of this trend at Pontecagnano is, therefore, highly significant for the social and political changes in the community.

\section{CONCLUSION}

Through the systematic analysis of burial contexts of the ancient city of Pontecagnano, it was attempted to gain a better understanding of the urbanization processes in Ancient Italy. Urbanization in Italy went hand in hand with state formation: settlement centralization occurred at the time of the establishment of a political class of rulers who signaled wealth and sustained power via ostentatious burial rites. This process has been observed in several Italian cities, all dated around the late eighth to seventh centuries BC. The cities started as a collection of settlement and burial nuclei, whose integration has been disputed. It is now, however, thought that a minimum of integration must have existed before settlement centralization (Fulminante, 2014).

Even though the broad outline of the urbanization phenomenon had been defined (a process of settlement centralization), many questions remained still unanswered. In particular, the dynamics at a micro and meso level were not well-understood: how state power developed and how state power could have influenced settlement centralization and urbanization. It was outlined how archaeologists consider state power as the result of a process of social differentiation and power struggles between interest groups in communities. It was explained how, in absence of other archaeological traces, burials provide the key to understanding processes 

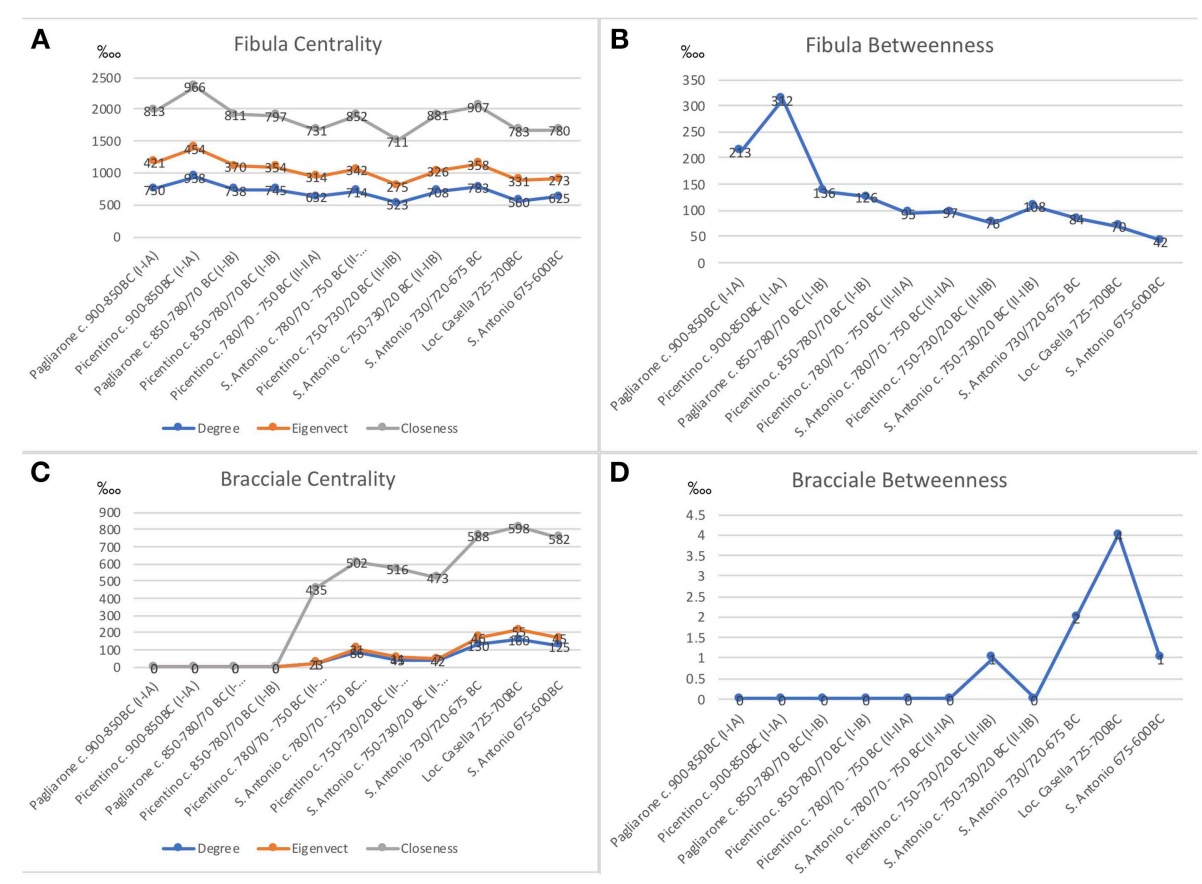

FIGURE 10 | Graph displaying Centrality values for selected metal objects related to bodily adornment: (A) fibula Degree, Eigenvector, and Closeness Centrality (scale \%oo), (B) fibula Betweenness Centrality (scale \%oo), (C) bracelet (bracciale) Degree, Eigenvector, and Closeness Centrality (scale \%oo), (D) bracelet (bracciale) Betweenness Centrality (scale \%oo).

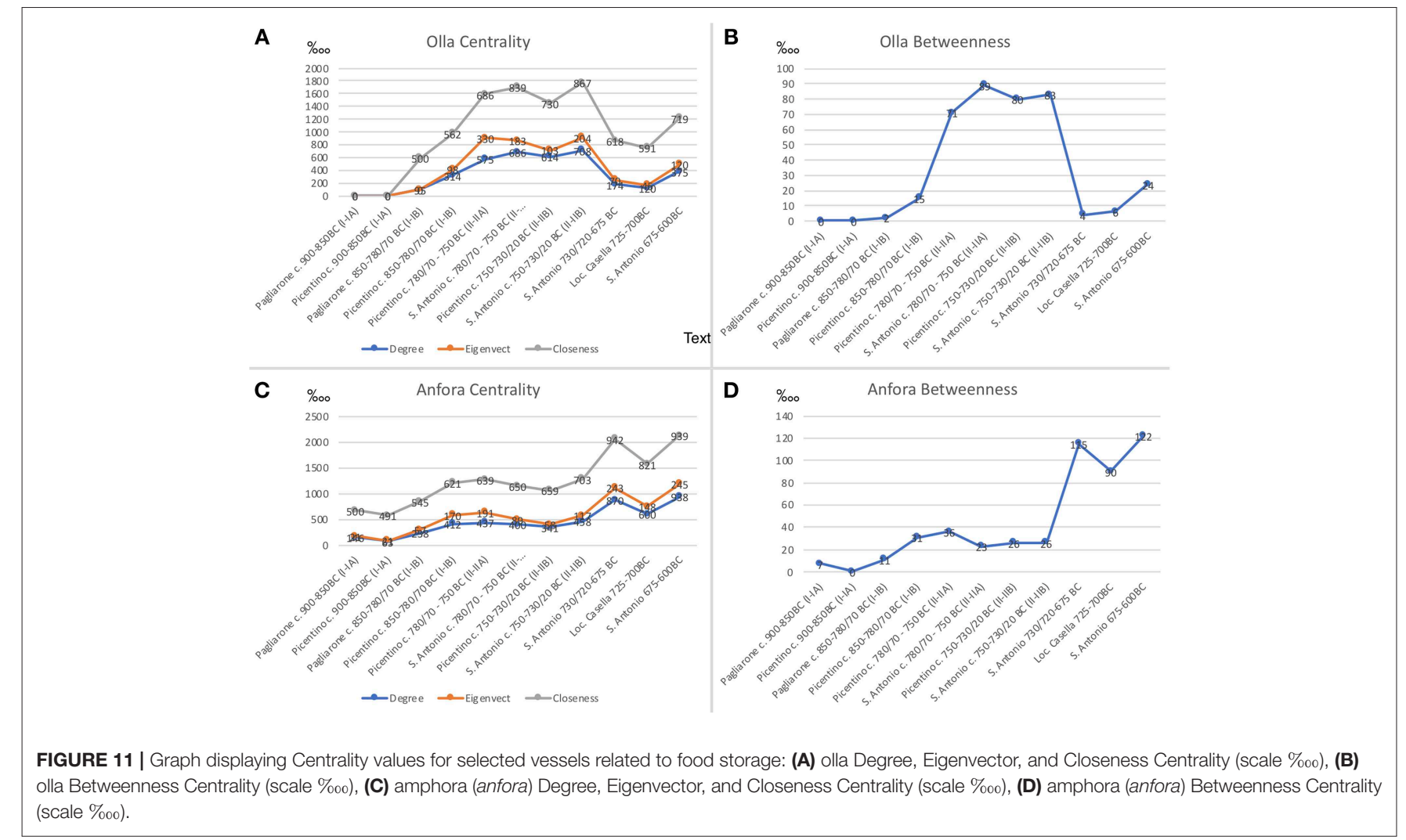


of social differentiation. As burial might have been one of the most, if not the most, important context for the creation of collective memory, expression of power and political negotiation in the region at that time, they are a particularly rich source to study state formation, and ultimately, urbanization.

The analysis departed from a model adapted from social network analysis: the two mode model or affiliation model (Borgatti et al., 2013). The model was initially developed to study social interaction and the formation of communities through shared interaction in the Deep South of the US (Davis et al., 1941). The general assumption of the study and, more generally, in network theory, is that (1) people who interact closely together form communities and share various behaviors and norms, (2) behaviors can be plotted in similarity matrices and graphs to provide a "tool to think with."

The notion of "community" was considered to provide a solid theoretical base both in terms of urban studies and network theory. The Davis model for community detection and interaction was adapted to fit an archaeological reality in which material patterns are seen as a proxy for human interaction: material similarities or "homophily" are considered a sign of cohesion in the community, dissimilar patterns as a sign of diversification.

With the two mode model, networks for different datasets were constructed. The datasets stem from excavation data of different burial plots over time. The networks, essentially similarity matrices, were further analyzed using a standard network analysis software, UCINet.

The analysis revealed firstly that the development of diversification in burial was not a linear process. In fact, in the later ninth and earlier eighth century BC, there was either a decline in the minimum and maximum number of objects that were deposited in the tombs, and if there was not so much a decline in differentiation through numbers, then there was a lack of diversity in the types of objects placed in the tombs. These patterns can be considered highly significant for the existence of an authority who controlled burial practices and who imposed rules that agents tried to circumvent through innovation. For example, T 2145 of the Picentino necropolis of phase I-IB was a tomb with one of the highest degree values for that plot at that time (it contained 17 objects, including weapons and a large storage vessel). In terms of content and diversity, the tomb was not radically different from others. But, space had been manipulated: the tomb was located at the center of a group of monumentalized tombs, while it was itself monumentalized with a platform that was shaped like a horse shoe (d'Agostino and Gastaldi, 1988). This innovation in the use of space had not existed before, and it can be suggested that new solutions were sought for status display, in other ways than in depositing objects. These sorts of tensions are highly significant for the study of diversification within the community and the existence of different strategies for social competition. Patterns like these can only be revealed by looking at global network metrics of Cohesion, in addition to local measures of Centrality-combined with qualitative analysis of the use of space.
The study of the circulation of selected object categories revealed several interesting and highly significant trends for state formation and urbanization. The analysis registered the decline of several traditional pottery shapes (tazza, scodella, brocca, askos) that found easy substitution with new painted fine wares that were imported from elsewhere after ca. the mid-eighth century BC. The traditional handmade attingitoio continued to be used and even increased in popularity, suggestive for a continuity in certain traditional practices that might have included ritual agency attributed to this particular vessel shape.

Traditional forms of gender-related status such as weaving equipment, swords and ceramic helmets also declined over time. Dramatic social changes and changing social values accompanied the rise of the state and advance of urbanization and led to the abandonment of certain traditional practices. The analysis, in contrast, registered the continuity in the use of lances and spears. This is a significant development that hints at the adoption of hoplite warfare, a phenomenon that scholars have (controversially) sought to relate to the establishment of the polis in the Greek world (Viggiano, 2013).

The last significant trend that the analysis revealed was the increased emphasis on storage vessels in the tombs after $c$. the mid-eighth century BC. Storage vessels signaled agricultural wealth, the latter being a condition for citizenship and political rights in most Ancient agrarian states. Moreover, the collection, storage and redistribution (or repurposing) of agricultural surpluses required an increased control over populations and appropriate facilities. Thus, settlement centralization and increased state power were often fueled by this process. Urbanization and the collection of surpluses are indicative of what the sociologist Mann (1984) calls increased "infrastructural power" of the state: an authority that imposes itself through bottom-up action in the daily life of the inhabitants.

The control of burial rites and "expenditure" suggests that political power at Pontecagnano predated the appearance of the city as centralized settlement proper. An authority was invested with the power to control burial and thus collective memory. The authority might have had a certain control over resources and redistribution of resources, such as bronze, as well. Even though scoring "low" on Michael Mann's scale of despotic and infrastructural power (Mann, 1984), this type of power is characteristic for "the state."

The early state at Pontecagnano, moreover, must also have had a say on the use of space, given the close proximity of the burial plots. Communal space, e.g., grazing grounds, quarries for clay, and stone as well as field boundaries had to be managed. This means that, despite the physical fragmentation of settlement nuclei and burial plots, "the state" at Pontecagnano was spatially bound and consisted of interconnected nuclei-i.e., a network.

We often think of settlement centralization as the moment of "birth" of the city. This is also reflected in the nomenclature "pre-urban," "proto-urban," and "urban." However, as the present analysis suggests, change at Pontecagnano is not radical and 
clearly part of a broader process of state transformation rather than formation. Settlement centralization is just one strategy adopted by the state to exercise infrastructural power. It just happens to be a transformation that has a high archaeological visibility and thus appears to constitute a radical break with the past. Alternatively, studying different settlement nuclei as part of a network in perpetual transformation allows to capture its social functioning, interdependence and manipulation of space much better. One can, therefore, wonder if the term "low density urbanism" might not be more appropriate to describe the situation in Early Iron Age Italy, rather than the terms "pre-urban" and "urban," which are a priori invested with specific values. "Low density urbanism" has been investigated for prehistoric settlement processes in Central Europe as well as the Maya in Mesoamerica and Iron Age oppida (Fletcher, 2011; Chapman and Gaydarska, 2016; Moore, 2017) and it places emphasis on the connectedness of settlement within a social system, rather than the categorical value of space and settlement density. "Low density urbanism" thus provides a more productive anchor point for comparative analysis and interdisciplinary dialogue on the formation of the Ancient City.

\section{REFERENCES}

Bartoloni, G. (1989). La Cultura Villanoviana: Allinizio Della Storia Etrusca. Rome: Carocci.

Bevan, A., and Lake, M. (eds.). (2013). Computional Approaches to Archaeological Space. London: Routledge.

Bintliff, J. (1999). "Settlement and territory," in Companion Encyclopaedia of Archaeology, ed. G. Barker (London: Routledge), 505-544.

Bintliff, J. (2000). "Settlement and territory: a socio- ecological approach to the evolution of settlement systems," in Human Ecodynamics, eds. G. Bailey, R. Charles, and N. Winder (Oxford: Oxbow Books), 21-30.

Bintliff, J. (2002). "Rethinking early mediterranean urbanism," in Mauerschau, Bd. 1. Festschrift für Manfred Korfmann, eds. M. Korfmann and R. Aslan (Tübingen: Bernhard Albert Greiner), 153-177.

Bintliff, J. (2006). "City-country relationships in the 'Normal Polis", in City, Countryside, and the Spatial Organization of Value in Classical Antiquity, eds. R. M. Rosen and I. Sluiter. (Leiden: Brill), 13-32. doi: 10.1163/9789047409182_003

Bintliff, J. (2016). "Agency and structure and the unconscious long durée," in Eurasia at the Dawn of History: Urbanization and Social Change, eds. M. Fernandez-Götz and D. Krausse (Cambridge: Cambridge University Press), 243-253. doi: 10.1017/9781316550328.016

Bintliff, J., Farinetti, E., Slapšsak, B., and Snodgrass, A. (2017). Boeotia Project, Volume II: The City of Thespiai: Survey at a Complex Urban Site. Oxford: Oxbow Books.

Blake, E. (2014). Social Networks and Regional Identity in Bronze Age Italy. Cambridge: Cambridge University Press. doi: 10.1017/CBO9781139879262

Boissevan, J. (1979). Network analysis: a reappraisal. Curr. Anthropol. 20, 392-394. doi: $10.1086 / 202277$

Boissevan, J., and Mitchell, J. (eds.). (1973). Network Analysis: Studies in Human Interaction. The Hague: Mouton. doi: 10.1515/9783110877779

Bonaudo, R., Cerchiai, L., Pellegrino, C. (2009). "Le necropoli di Pontecagnano: studi recenti," in Tra Etruria, Lazio e Magna Grecia: Indagini Sulle Necropoli, eds. R. Bonaudo, L. Cerchiai and C. Pellegrino (Paestum: Tekmeria), 169-209.

Borgatti, S., Everett, M., and Freemann, L. C. (2002). Ucinet 6 for Windows Software for Social Network Analysis. Harvard.

Borgatti, S., Everett, M., Johnson, J., and Freemann, L. C. (2013). Analysing Social Networks. London: Sage.

Borgatti, S. P., and Everett, M. G. (1997). Network analysis of 2-mode data. Soc. Netw. 19, 243-269. doi: 10.1016/S0378-8733(96)00301-2

\section{AUTHOR CONTRIBUTIONS}

The author confirms being the sole contributor of this work and has approved it for publication.

\section{FUNDING}

This paper was published thanks to OPEN-AIRE funding granted to Francesca Fulminante for the Marie Sklodowska IEF PastPeople-Nets 628818 conducted at the University of Roma Tre (2014-2016).

\section{ACKNOWLEDGMENTS}

I wish to thank the funding bodies that have made my research during the last years possible: Georg-August-Universität Göttingen (Dorothea Schlözer program 2014-2016) and the Horizon 2020 program (Marie Skłodowska Curie Fellowship grant no. 702511 in 2016-2018). My thanks also goes to the peer reviewers who helpfully commented on an earlier version of this text.

Brughmans, T. (2010). Connecting the dots: towards archaeological network analysis. Oxf. J. Archaeol. 29, 277-303. doi: 10.1111/j.1468-0092.2010. 00349.x

Brughmans, T. (2012a). "Facebooking the past: a critical social network analysis approach for archaeology," in Thinking Beyond the Tool: Archaeological Computing and the Interpretative Process, eds. A. Chrysanti, P.M. Flores and C. Papadopoulos (Oxford: Archaeopress), 191-203.

Brughmans, T. (2012b). Thinking through networks: a review of formal network methods in archaeology. J. Archaeol. Method Theory 20, 623-662. doi: 10.1007/s10816-012-9133-8

Brughmans, T., and Brandes, U. (2017). Visibility network patterns and methods for studying visual relational phenomena in archeology. Front. Digital Human. 4:17. doi: 10.3389/fdigh.2017.00017

Burt, R. (1995). Structural Holes: The Social Structure of Competition. Cambridge, MA: Harvard University Press.

Canuto, M. A., and Yaeger, J. (2000). The Archaeology of Communities: a New World Perspective. London: Routledge.

Carandini, A. (2018). Rome: Day One. Princeton, NJ: Princeton University Press.

Carrington, P. J., and Scott, J. (2011). The SAGE Handbook of Social Network Analysis. London: SAGE.

Cerchiai, L. (1987). Una tomba principesca del periodo Orientalizzante Antico a Pontecagnano. Studi Etruschi LIII, 27-42.

Cerchiai, L., Cinquantaquattro, T., and Pellegrino, C. (2013). "Dinamiche etnicosociali e articolazioni di genere nell'Agro Picentino," in Nuove Frontiere per la Storia di Genere, Vol II, eds. L. Guidi and M. R. Pelizzari (Salerno: Università degli Studi di Salerno), p. 77-93, p. 88.

Chapman, J., and Gaydarska, B. (2016). "Low-density urbanism: the case of the Trypillia group of Ukraine," in Eurasia at the Dawn of History, eds. M. Fernández-Götz and D. Krausse (Cambridge: Cambridge University Press), 81-105. doi: 10.1017/9781316550328.006

Childe, G. (1950). The urban revolution. Town Plan. Rev. 21, 3-17. doi: 10.3828/tpr.21.1.k853061t614q42qh

Cinquantaquattro, T. (2001). Pontecagnano, 2, 6. Lagro Picentino e la necropoli di località Casella. Naples: Istituto Universitario Orientale.

Collar, A. (2013). Religious Networks in the Roman Empire: The Spread of New Ideas. Cambridge: Cambridge University Press. doi: 10.1017/CBO9781107338364

Collar, A., Coward, F., Brughmans, T., and Mills, B. (2015). Networks in archaeology: phenomena, abstraction, representation. J. Archaeol. Method Theory 22, 1-32. doi: 10.1007/s10816-014-9235-6 
Cuozzo, M. (2003). Reinventando la Tradizione. Immaginario Sociale, Ideologie e Rappresentazione Nelle Necropoli Orientalizzante di Pontecagnano. Paestum: Pandemos.

Cuozzo, M., D'Andrea, A., and Pellegrino, C. (2004). "The use of space in the etruscan cemeteries of pontecagnano (Salerno, Italy) in the orientalising period (8th - 7th century BC)," in Spatial Analysis of Funerary Areas, eds. L. Šmejda and J. Turek (Pilsen: University of West Bohemia), 142-147.

d'Agostino, B. (1968). Pontecagnano. Tombe orientalizzanti in contrada S. Antonio. Notizie degli scavi dell'Antichià XXII, 75-204.

d'Agostino, B., and Gastaldi, P. (1988). Pontecagnano. II. La necropoli del Picentino. 1. Le tombe della Prima Età del Ferro. Naples: Istituto Universitario Orientale.

d'Agostino, B., and Gastaldi, P. (2012). "Pontecagnano nel terzo quarto del' VIII secolo a.C.," in Interpretando l'antico. Scritti di archeologia offerti a Maria Bonghi Jovino, eds. C. Chiaramonte Trerè, G. Bagnasco Gianni, and F. Chiesa (Milano: Cisalpino), 389-434.

d'Agostino, B., and Gastaldi, P. (2016). "La cultura orientalizzante tirrenica come frutto di una crescita endogena: l'esempio di Pontecagnano," in Contexts of Early Colonization, eds. L. Donnellan, V. Nizzo, and G. J. Burgers (Rome: KNIR), 159-176.

Damgaard Andersen, H. (eds.). (1997). Urbanization in the Mediterranean in the 9th to 6 th Centuries BC. Copenhagen: Museum Tusculanum Press.

Davis, A., Gardner, B., and Gardner, M. (1941). Deep South. A Social Anthropological Study of Caste and Class. Chicago, IL: University of Chicago Press.

De Natale, S. (1992). Pontecagnano. II. La necropoli di S. Antonio: Propr. ECI. 2. Tombe della prima Età del Ferro. Naples: Istituto Universitario Orientale.

De Natale, S. (2016). Pontecagnano II.7. La necropoli del Picentino. Tombe della Prima Età del Ferro dalla proprietà Colucci. Naples: Istituto Universitario Orientale.

di Gennaro, F. (1982). Organizzazione del territorio nell'Etruria meridionale protostorica: applicazione di un modello grafico. Dialog. Archeol. 2, 102-112.

di Gennaro, F. (1986). Forme di insediamento fra Tevere e Fiora dal Bronzo Finale al principio dell'et à del Ferro. Florence: Olschki.

Donnellan, L. (2016a). 'Greek colonisation' and Mediterranean networks: patterns of mobility and interaction at Pithekoussai. J. Greek Archaeol. 1, 109-148.

Donnellan, L. (2016b). "A networked view on Euboean 'colonisation", in Conceptualising Early Colonisation, eds. L. Donnellan, V. Nizzo, and G. J. Burgers (Turnhout: Brepols), 149-166.

Donnellan, L. (2017). "The "Euboean koine". Reassessing patterns of crosscultural interaction and exchange in the north-western Aegean region," in Material Koinai in the Greek Early Iron Age and Archaic Period (Proceedings and Monographs of the Danish Institute at Athens), ed. S. Handberg and M. Gaddolou (Aarhus: Aarhus University Press), 43-63.

Donnellan, L. (2019). "Changing pottery production technologies in urbanizing societies in the Bay of Naples (8th-7th centuries BCE)," in Habitus, the Social Dimension of Technology and Transformation, ed. S. Kadrow and J. Müller (Leiden: Sidestone Press), 161-180.

Ducke, B., and Kroefges, P. (2008). "From points to areas: constructing territories from archaeological site patterns using an enhanced Xtent model," in Layers of Perception. Proceedings of the 35th International Conference on Computer Applications and Quantitative Methods in Archaeology (CAA), eds. A. Posluschny, K. Lambers and I. Herzog (Bonn: Habelt Verlag), 245-251.

Egg, M. (2017). "War and weaponry," in Etruscology, ed. A. Naso (Berlin: De Gruyter), 165-177. doi: 10.1515/9781934078495-011

Farinetti, E. (2009). Boeotian Landscapes: A GIS-Based Study for the Reconstruction and Interpretation of the Archaeological Datasets of Ancient Boeotia. Oxford: Oxbow Books.

Fernandez-Götz, M., and Krausse, D. (eds.). (2016). Eurasia at the Dawn of History: Urbanization and Social Change. Cambridge: Cambridge University Press. doi: $10.1017 / 9781316550328$

Fletcher, R. (2011). "Low-Density, Agrarian-based urbanism," in The Comparative Archaeology of Complex Societies, ed. M. Smith (Cambridge: Cambridge University Press), 285-320. doi: 10.1017/CBO9781139022712.013

Fulminante, F. (2003). Le "sepulture principesche" nel Latium Vetus tra la fine dell' età del Ferro e l'inizio dell'età Orientalizzante. Rome: L'Erma di Brettschneider.

Fulminante, F. (2012a). "Ethnicity, identity and state formation in the Latin landscape: problems and approaches," in Landscape, Identity and Ethnicity in the Archaic Mediterranean Area, eds. G. Cifani and S. Stoddart (Oxford: Oxbow Books), 89-107. doi: 10.2307/j.ctvh1dkcp.11

Fulminante, F. (2012b). Social network analysis and the emergence of central places: a case study from bronze and early iron age central Italy. BaBesch $87,1-27$.

Fulminante, F. (2014). The Urbanization of Rome and Latium Vetus From the Bronze Age to the Archaic Era. Cambridge: Cambridge University Press. doi: 10.1017/СBO9781139343404

Fulminante, F., Prignano, L., Morer, I., and Lozano, S. (2017). Coordinated decisions and unbalanced power. How Latin cities shaped their terrestrial transportation network. Front. Digital Human. 4:4. doi: 10.3389/fdigh.2017.00004

Fulminante, F., and Stoddart, S. (2010). Formazione politica a confronto in Etruria e Latium vetus: status quaestionis e nuove prospettive di ricercar. Bollettino di Archeologia Online. Volume speciale, 11-22.

Fulminante, F., and Stoddart, S. (2012). "Indigenous political dynamics and identity from a comparative perspective: Etruria and Latium Vetus," in Exchange Networks and Local Transformations, eds. M. E. Alberti and S. Sabatini (Oxford: Oxbow Books), 117-133. doi: 10.2307/j.ctvh1dm19.15

Fustel de Coulange, N. (1980). The Ancient City (trad.). Baltimore, MD: The John Hopkins University Press.

Gastaldi, P. (1998). Pontecagnano. II.4 La necropoli del Pagliarone. Naples: Istituto Universitario Orientale.

Gastaldi, P. (2016). Pontecagnano III. Dizionario Della Cultura Materiale, Fascicolo 1. La Prima Età del Ferro. Naples: Istituto Universitario Orientale.

Gleba, M. (2015). "Production and consumption: textile economy and urbanization in Mediterranean Europe 1000-500 BCE (PROCON)," in Aspects of the Design, Production and Use of Textiles and Clothing from the Bronze Age to the Early Modern Era, eds. K. Grömer and F. Pritchard (Budapest: Archaeolingua), 261-269.

Gottdiener, M., Butt, L., and Lehtovuori, P. (2005). Key Concepts in Urban Studies. London:SAGE. doi: 10.4135/9781446279120

Granovetter, M. (1973). The strength of weak ties. Am. J. Sociol. 78, 1360-1380. doi: $10.1086 / 225469$

Groenhuijzen, M., and Verhagen, P. (2017). Comparing network construction techniques in the context of local transport networks in the Dutch part of the Roman limes. J. Archaeol. Sci. Rep. 15, 235-251. doi: 10.1016/j.jasrep.2017.07.024

Guidi, A. (1985). "An application of the rank-size rule to proto-historic settlement in the middle Tyrrhenian area," in Patterns in Proto-History, eds. S. Stoddart and C. Malone (Oxford: Archaeopress), 217-242.

Guidi, A. (1998). The emergence of the state in central and northern Italy. Acta Archaeol. 69, 139-161.

Guidi, A. (2008). Archeologia dell'Early state: il caso di studio italiano. Ocnus $16,175-192$.

Jaspers, K. (1949). Vom Ursprung und Ziel der Geschichte. Zürich: Fischer Bucherei. Knappett, C. (2011). An Archaeology of Interaction. Network Perspectives on Material Culture and Society. Oxford: Oxford University Press. doi: 10.1093/acprof:osobl/9780199215454.001.0001

Knappett, C. (ed.). (2013). Network Analysis in Archaeology. New Approaches to Regional Interaction. Oxford: Oxford University Press. doi: 10.1093/acprof:oso/9780199697090.001.0001

Laneri, N. (2007). Performing Death: Social Analysis of Funerary Traditions in the Ancient Near East and Mediterranean. Chicago, IL: University of Chicago Press.

Leidwanger, J., Knappett, C., Arnaud, P., Arthur, P., Blake, E., Broodbank, C., et al. (2014). A manifesto for the study of ancient Mediterranean maritime networks. Antiquity 88.

Li, X., and Gong, P. (2016). Urban growth models: progress and perspective. Sci. Bull. 61, 1637-50. doi: 10.1007/s11434-016-1111-1

Mac Sweeney, N. (2011). Community Identity and Archaeology: Dynamic Communities at Aphrodisias and Beycesultan. Ann Arbor, MI: University of Michigan Press. doi: 10.3998/mpub.3080464

Mann, M. (1984). The autonomous power of the state: its origins, mechanisms and results. Eur. J. Sociol. 25, 185-213. doi: 10.1017/S0003975600004239

McPherson, M., Smith-Lovin, L., and Cook, J. M. (2001). Birds of a feather: homophily in social networks. Annu. Rev. Sociol. 27, 415-444. doi: 10.1146/annurev.soc.27.1.415 
Mills, B., Clark, J., Peeples, M., Haas, R. J., Roberts, J. M. Jr., Hill, J., et al. (2013). Transformation of social networks in the late pre-hispanic US Southwest. Proc. Natl. Acad. Sci. U.S.A. 110, 5785-5790. doi: 10.1073/pnas.12199 66110

Mills, B., Peeples, M., Haas, R., and Borck, L. (2015). Multiscalar perspectives on social networks in the Late Hispanic Southwest. Am. Antiquity 80, 3-24. doi: 10.7183/0002-7316.79.4.3

Mizruchi, M. S., and Schwartz, M. (1992). Intercorporate Relations: the Structural Analysis of Business. Cambridge: Cambridge University Press.

Moore, T. (2017). Beyond iron age 'towns': examining oppida as examples of low-density urbanism. Oxf. J. Archaeol. 36, 287-305. doi: 10.1111/ojoa.12116

Moreno, J. (1934). Who Shall Survive? A New Approach to the Problem of Human Interrelations. Washington, DC: Nervous and Mental Disease Publishing Co. doi: $10.1037 / 10648-000$

Morgan, C. (2003). Early Greek States Beyond the Polis. London: Routledge. doi: 10.4324/9780203417751

Motta, L., and Terrenato, N. (2006). "The origins of the State par excellence. Power and society in Iron Age Rome," in Celtes et Gaulois, l'Archéologie face à l'Histoire, 4: les mutations de la fin de l'âge du Fer. Actes de la table ronde de Cambridge, 7-8 juillet 2005, ed. C. Haselgrove (Glux-en-Glenne: Bibracte, Centre archéologique européen), 225-234

Nijboer, A. (1997). "The role of craftsmen in the urbanization process of Central Italy (8th to 6th centuries BC)," in Urbanization in the Mediterranean in the 9th to 6th Centuries BC, ed. H. Damgaard Andersen (Copenhagen: Museum Tusculanum Press), 383-406.

Nizzo, V. (2015). Archeologia e Antropologia Della Morte: Storia di un Idea. Bari: Edipuglia.

Nizzo, V. (2016). "Lo spazio funerario. Per una stratigrafia dei rapporti sociali: parentela, rito, tempo e filtri funerari nella necropoli di Pithekoussai," in Poleis e politai nella Magna Grecia Archaica e Classica (Taranto: ISAMG), 417-457.

Opsahl, T. (2013). Triadic closure in two-mode networks: redefining the global and local clustering coefficients. Soc. Netw. 35. doi: 10.1016/j.socnet.2011.07.001

Osborne, R. (2005). "Urban sprawl. What is urbanization and why does it matter?" in Mediterranean Urbanization 800 - 600 B.C., eds. R. Osborne and B. Cunliffe (Oxford: Oxford University Press), 1-16. doi: $10.5871 /$ bacad/9780197263259.003.0001

Osborne, R., and Cunliffe, B. (eds.). (2005). Mediterranean Urbanization 800 - 600 B.C. Oxford: Oxford University Press. doi: 10.5871/bacad/9780197263259.001.0001

Östborn, P., and Gerding, H. (2015). The diffusion of fired bricks in hellenistic europe: a similarity network analysis. J. Archaeol. Method Theory 22, 306-44. doi: 10.1007/s10816-014-9229-4

Pacciarelli, M. (2001). Dal villaggio alla città. La svolta proto-proto-urbana del 1000 a.C. nell'Italia tirrenica. Florence: Insegna del Giglio.

Padgett, J. F., and Ansell, C. K. (1993). Robust action and the rise of the Medici, 1400-1434. Am. J. Sociol. 98, 1259-1319. doi: 10.1086/230190

Peeples, M. (2018). Connected Communities. Networks, Identities and Social Change in the Ancient Cibola World. Tuscon, AZ: The University of Arizona Press. doi: 10.2307/j.ctt1ws7wrq

Pellegrino, C. (2015). "Pontecagnano e l'Agro Picentino: processi sociali, dinamiche territoriali e di strutturazione urbana tra VIII e VII secolo a.C.," in Early Iron Age Communities of Southern Italy, eds. G. Saltini Semerari and G.J. Burgers (Rome: KNIR), 26-47.

Peroni, R. (2000). "Formazione e sviluppi dei centri protourbani medio-tirrenici," in Roma, Romolo, Remo e la fondazione della città, eds. A. Carandini and R. Cappelli (Milan: Electa), 26-30.

Redhouse, D. I., and Stoddart, S. (2011). "Mapping Etruscan State formation," in State Formation in Italy and Greece. Questioning the Neoevolutionist Paradigm, eds. N. Terrenato, and D. Haggis (Oxford: Oxbow Books), 161-178.

Riva, C. (2010). The Urbanization of Etruria: Funerary Practices and Social Change, 700-600 BC. Cambridge: Cambridge University Press. doi: 10.1017/CBO9781316136515
Riva, C., and Vella, N. (2006). Debating Orientalisation. Multidisciplinary Approaches to Change in the Ancient Mediterranean. London: Equinox Publishers.

Rivers, R., Knappett, C., and Evans, T. (2013a). "What makes a site important? Centrality, gateways, and gravity," in Network Analysis in Archaeology. New Approaches to Regional Interaction, ed C. Knappett (Oxford: Oxford University Press), 125-150. doi: 10.1093/acprof:oso/9780199697090.003.0006

Rivers, R., Knappett, C., and Evans, T. (2013b). "Network models and archaeological spaces," in Computional Approaches to Archaeological Space, eds. A. Bevan and E. Lake (London: Routledge), 99-126.

Simmel, G. (1903). Die Großstädte und das Geistesleben. Dresden: Suhrkamp Verlag.

Sindbæk, S. (2013). "Broken links and black boxes: material affiliations and contextual network synthesis in the Viking World," in Network Analysis in Archaeology. New Approaches to Regional Interaction, ed. C. Knappett (Oxford: Oxford University Press), 71-94. doi: 10.1093/acprof:oso/9780199697090.003.0004

Spengler, O. (1922). Der Untergang des Abendlandes. Wien: Verlag Braumüller.

Stoddart, S. (1999). "Urbanization and state formation," in Companion Encyclopedia of Archaeology, ed. G. Barker (London: Routledge), 908-49.

Van Oyen, A. (2016). "Networks or work-nets? Actor-network theory and multiple social topologies in the production of Roman terra sigillata," in The Connected Past. Network Studies in Archaeology and History, eds. T. Brughmans and A. F. Coward (Oxford: Oxford University Press), 35-56.

Van Oyen, A. (2017). Agents and commodities: a response to Brughmans and Poblome (2016) on modelling the Roman economy. Antiquity 91, 356-363. doi: 10.15184 /aqy.2017.138

Vanzetti, A. (2002). "Results and problems of some current approaches to protohistoric centralization and urbanization in Italy," in New Developments in Italian Landscape Archaeology. Theory and Methodology of Field Survey, Land Evaluation and Landscape Perception, Pottery Production and Distribution, ed P. Attema (Oxford: Archaeopress), 36-51.

Varien, M.D., and Potter, J. (eds.). (2011). The Social Construction of Communities: Agency, Structure, and Identity in the Prehispanic Southwest. Lanham: Rowman and Littlefield Publishers.

Verhagen, P. (2018). "Predictive modeling," in The Encyclopedia of Archaeological Sciences, ed. S. López Varela (Chichester: Wiley-Blackwell) doi: 10.1002/9781119188230.saseas0475

Viggiano, G. F. (2013). "The hoplite revolution and the rise of the polis," in Men of Bronze. Hoplite Warfare in Ancient Greece, ed D. Kagan (Princeton, NJ: Princeton University Press), 112-132. doi: 10.1515/9781400846306-009

Ward Perkins, J. B. (1961). Veii: The Historical Topography of the Ancient City. Pap. Br. Sch. Rome 29, 1-123. doi: 10.1017/S0068246200011028

Wasserman, S., and Faust, K. (1994). Social Network Analysis: Methods and Applications. Cambridge: Cambridge University Press. doi: 10.1017/CBO9780511815478

Weber, M. (1921). Die Stadt. Tübingen: Mohr.

Wellman, B., and Berkowitz, S. (1988). Social Structures: a Network Approach. Cambridge: Cambridge University Press.

Yoffee, N. (2005). Myths of the Archaic State: Evolution of the Earliest Cities, States and Civilizations. Cambridge: Cambridge University Press.

Conflict of Interest Statement: The author declares that the research was conducted in the absence of any commercial or financial relationships that could be construed as a potential conflict of interest.

Copyright (c) 2019 Donnellan. This is an open-access article distributed under the terms of the Creative Commons Attribution License (CC BY). The use, distribution or reproduction in other forums is permitted, provided the original author(s) and the copyright owner(s) are credited and that the original publication in this journal is cited, in accordance with accepted academic practice. No use, distribution or reproduction is permitted which does not comply with these terms. 